\title{
Reduced n-3 highly unsaturated fatty acids dietary content expected with global change reduces the metabolic capacity of the golden grey mullet
}

\author{
Vagner Marie ${ }^{1,2,{ }^{*}}$, Zambonino-Infante Jose-Luis ${ }^{3}$, Mazurais David ${ }^{3}$, Imbert-Auvray Nathalie ${ }^{1,3}$, \\ Ouillon Natascha ${ }^{1}$, Dubillot Emmanuel ${ }^{1}$, Le Delliou Herve ${ }^{3}$, Akbar David ${ }^{1}$, Lefrancois Christel ${ }^{1}$
}

${ }^{1}$ Inst Littoral \& Environm, UMR LIENSs 7266, F-17000 La Rochelle, France.

2 Evolution Symbiose, UMR 7267 EBI Lab Ecol, F-86022 Poitiers, France.

3 IFREMER, LEMAR, UMR 6539, ZI Pointe Diable, F-29280 Plouzane, France.

*Corresponding author : Marie Vagner, email address : marie.vagner@univ-Ir.fr

\begin{abstract}
:
In this study, we hypothesised that a reduction in n-3 HUFA availability for higher consumers, as expected with global change, would negatively impact the physiological performances of fish. The aim was to experimentally evaluate the effect of n-3 HUFA dietary content on cardio-respiratory performances of the golden grey mullet (Liza aurata), a microalgae grazer of high ecological importance in European coastal areas. These performances were evaluated in terms of critical swimming speed $U$ (crit), associated oxygen consumption $\mathrm{MO2}$, post-exercise oxygen consumption and calcium fluxes in cardiomyocytes. Two replicated groups of fish were fed on a rich (standard diet, SD diet: $1.2 \% n-3$ HUFA on dry matter basis, DMB) or a poor n-3 HUFA (low n-3 HUFA diet, LD diet: $0.2 \%$ n-3 HUFA on DMB) diet during 5 months and were called SD and LD groups, respectively. The results showed that the LD diet reduced growth rate as well as the aerobic capacity of L. aurata at $20 \mathrm{~A}$ degrees $\mathrm{C}$, suggesting that fish may have to save energy by modifying the proportion of energy allocated to energydemanding activities, such as digestion or feeding. In addition, this LD diet induced higher levels of haematocrit and plasma osmolality, indicating a stress response at the second and third levels in that group. However, the LD diet caused a massive increase in swimming efficiency. This should improve the capacity of L. aurata to migrate and to forage over a wide area. In turn, these could then compensate for the reduction in growth rate and aerobic metabolism.
\end{abstract}

\section{Introduction}

In coastal environments, highly polyunsaturated fatty acids from the $n-3$ series, otherwise known as n-3 HUFA, are mainly supplied by the dominating diatoms, which represent an important lipid source for secondary producers (Kates and Volcani 1966; Roessler 1988; Pahl et al. 2010; Crawford and Broadhurst 2012). Indeed, n-3 HUFA are weakly synthesised de novo by higher organisms, while they function as critical structural and physiological 
components of the cell membranes of most tissues (Sargent et al. 2002). In marine fish, membranous n-3 HUFA are dominated by ecosapentaenoic acid (EPA, 20:5n-3) and docosahexaenoic acid (DHA, 22:6n-3; for reviews see Sargent et al. 2002; Glencross 2009; Tocher 2010). They are essential for growth, survival, pigmentation, development and functionality of the brain, vision, and the nervous system, as well as in resistance to stress and disease, as they are precursors of eicosanoids (for reviews see Sargent et al. 2002; Glencross 2009; Tocher 2010).

Over the last twenty years, several studies have shown that diatoms growth rate and n3 HUFA profile largely decreased because of environmental variability related to global change (i.e. increasing temperature, $\mathrm{pH}$, and $\mathrm{UV}$; decreasing salinity and oxygen saturation (Béthoux et al. 1998; Gomez and Souissi 2008; Guschina and Harwood 2009; Pahl et al. 2010; Chen 2012). In addition, the changes in physicochemical parameters, hydrological regimes and precipitation patterns expected with global change would lead to an overenrichment of nitrogen and phosphate with respect to silica and would therefore be responsible for a shift from diatoms towards non-siliceous species (e.g. Phaeocystis) dominance, which are poorer in n-3 HUFA than diatoms (Owens et al. 1989; Goffart et al. 2002; Gypens et al. 2007; Gomez and Souissi 2008; Guschina and Harwood 2009).

In the context of global change, the expected variability of n-3 HUFA content at the base of the food web may propagate to higher trophic levels, because, in all animals, the fatty acid composition of the tissue partly depends on that of the diet (Bell et al. 1996; Leu et al. 2006). As mentioned above, n-3 HUFA are the main components of the membrane bilayer. Therefore, variability in n-3 HUFA dietary content may lead to variability in the membranous n-3 HUFA of higher consumers, despite the fact that membrane lipids are regulated to large extent. This would consequently induce changes in their membrane structure and function. 
Due to its role in membrane functionality, dietary n-3 HUFA content has been shown to further impact individual physiological performances, and in particular swimming and cardio-respiratory performances (McKenzie 2001; Wagner et al. 2004; Chatelier et al. 2006a; Chatelier 2006b). Swimming performance is essential because it determines food intake, predator avoidance, migratory capability and consequently the selection of favourable environmental conditions (Brett 1964; Domenici et al. 2013). For many researchers, swimming performance is therefore considered determinant of the Darwinian fitness of fish (Martinez 2003; Yan et al. 2013). Swimming performances are widely evaluated through the critical swimming speed $\mathrm{U}_{\text {crit, }}$ i.e., the water speed at which a fish can no longer maintain its position when exposed to a swim challenge through a step protocol (Brett 1964; Reidy et al. 2000; Lee 2003). Swimming performances are partly limited by the capacity of heart, which provides and regulates the internal energy of fish (Paige et al. 1996; McKenzie 2001; Chatelier et al. 2006a; Guderley et al. 2008). Heart capacity thereby determines aerobic metabolic scope (AS, Fry 1947), which is the difference between the active metabolic rate (AMR) and the standard metabolic rate (SMR), i.e. the maximal metabolic rate of an organism in a highly active state minus its metabolic rate when at rest (Fry 1971). AS estimates the capacity of oxygen allocation, i.e. the energy that an organism may allocate to its different energy-demanding activities (e.g. locomotion, digestion, feeding), and is often monitored because it is claimed to be a relevant proxy of fitness (Claireaux and Lefrancois 2007).

In the context of the environmental adaptation of organisms, it is essential to understand the influence of fatty acids on the swimming and cardio-respiratory performances of fish. However, only a few studies have reported this effect of fatty acids on fish, and they are conflicting. More than ten years ago, McKenzie (2001) showed that an enriched n-3 HUFA diet resulted in a decrease in SMR and AMR in the Adriatic sturgeon Acipenser 
naccarii and in the eel Anguilla anguilla. A reduced dietary n-3 HUFA content has also been shown to alter the mitochondrial respiratory capacity of rainbow trout (Onchorynchus mykiss) by changing the n-3 HUFA content in membranes, thus influencing the energy status of the animal (Guderley et al. 2008). Moreover, Wagner et al. (2004) suggested that low dietary n-3 HUFA/saturated fatty acids SFA and n-3 HUFA/arachidonic acid (AA; 20:4n-6) ratios may negatively affect the swimming performance of Atlantic salmon, as a negative correlation was found between these ratios and $U_{\text {crit. }}$ However, the opposite was reported in the same species by Dosanjh et al. (1998) and McKenzie et al. (1998), as well as in sea bass by Chatelier et al. (2006b). The latter studies reported that low n-3 HUFA dietary levels (replaced by high monounsaturated fatty acids MUFA content) in the diet always led to higher $U_{\text {crit }}$ in sea bass, suggesting a preferential use of MUFA than HUFA to provide the necessary energy to the animal. These inconsistent results reveal the importance of a better evaluation of the effect of n-3 HUFA dietary content on the swimming and cardio-respiratory performances of fish, particularly in the context of global change.

Therefore, the aim of this study was to test the effect of a reduction in n-3 HUFA dietary content on critical swimming speed, $\mathrm{U}_{\text {crit, }}$, and associated oxygen consumption, $\mathrm{MO}_{2}$, post-exercise oxygen consumption, as well as on calcium fluxes in cardiomyocytes of the golden grey mullet (Liza aurata). L. aurata is of high ecological importance in European coastal areas because it is a microalgae grazer and a trophic vector of organic matter from intertidal to subtidal area. Because of its diet, the mullet may be directly subject to the variability of n-3 HUFA availability in primary producers, as no intermediate trophic steps will buffer their biochemical variability. To perform this study, two experimental diets were used: a Standard diet (SD) used as a reference, and a Low-n-3 HUFA diet (LD), which was a 
Fish maintenance

All fish manipulations were performed according to the French ethics committee.

Juvenile golden grey mullets [initial mean weight \pm standard error (SE): $26.1 \pm 0.4 \mathrm{~g}$; initial

130 mean standard length $\pm \mathrm{SE}: 13.0 \pm 0.1 \mathrm{~cm}]$ were caught in an Italian lagoon (Cabras, Sardinia,

131 Italy) in 2011 and transported in aerated plastic bags $(n=2$ fish per plastic bag) to our

132 laboratory (Institut du Littoral et de l'Environnement, UMR 7266 CNRS-Université de La

133 Rochelle, France) where all experiments were conducted. Upon arrival, fish were transferred

134 into four indoor tanks (volume: $400 \mathrm{~L} ; \mathrm{n}=20$ fish per tank) that were individually supplied

135 with aerated recirculated sand-filtered natural seawater and equipped with an external

136 biological filter (Eheim professionnel 3 2080, Eheim, Deizisau, Germany). They were

137 progressively acclimated to the water tank temperature, which was kept constant by a

138 recirculating water system (TECO TR20, Conselice, Italy), and maintained in a temperature-

139 controlled room $\left(20^{\circ} \mathrm{C}\right)$ exposed to a $12 \mathrm{~L}: 12 \mathrm{D}$ photoperiod cycle. Temperature $\left(19.9 \pm 0.5^{\circ} \mathrm{C}\right)$,

140 salinity $(33.4 \pm 0.1)$ and oxygen $(87.9 \pm 2.6 \%$ air saturation $)$ were monitored daily using a

141 conductimeter (WTW model oxi 340i, WeiLDeim, Germany). After a few days of acclimation

142 to the experimental structure, fish were fed with a commercial diet (Le Gouessant ${ }^{\circledR}$

143 aquaculture, Lamballe, France) once a day for three weeks. Then, $24 \mathrm{~h}$-starved fish were

144 anaesthetised (tricaine methane sulphonate MS-222; $0.1 \mathrm{~g} \mathrm{~L}^{-1}$, Sigma-Aldrich, St Quentin-

145 Fallavier, France), weighed, and pit-tagged (M120; biolog-id, Réseaumatique, Bernay,

146 France).

147 Two experimental isolipidic and isoproteic diets differing by their n-3 HUFA content, were

148 made at the PFOM unit, UMR 6539 LEMAR (Plouzané, France): A standard diet SD (1.2\% 
EPA + DHA on dry matter basis), and a low-n-3 HUFA diet LD (LD: 0.2\% EPA + DHA on

150 dry matter basis $\mathrm{DMB}$ ) which was obtained by replacing the fish oil present in the standard

151 diet with soybean oil. For each of these two diets, two groups of fish ( $\mathrm{n}=2$ tanks, i.e. 40 fish

152 per dietary condition) were fed for 5 months $\left(2 \%\right.$ of biomass day $\left.{ }^{-1}\right)$. As the HUFA n-3 needs

153 were not known for L. aurata, SD was formulated according to the needs known for other

154 species. The n-3 HUFA level of that diet ranged between the optimum recommended in

155 yellow croaker (0.6-0.98\%; Zuo et al. 2012), gilthead seabream (0.9\%; Kalogeropoulos et al.

156 1992), juvenile flounder (0.8-1.0\%; Kim and Lee 2004) and juvenile starry flounder (at least

$1570.9 \%$ Lee et al. 2003), and that recommended in juvenile cobia Rachycentron canadum

158 (1.49\%; Liu et al. 2007) and juvenile cod Hexagrammo sotakii (1.2-1.7\%, Lee and Cho 2009).

159 The composition and fatty acid content of the two diets are summarised in Table 1.

160

161 Lipid analysis

162

163 Lipid analysis was performed on the muscle of 12 individuals for each experimental

164 condition. For each fish, whole frozen muscle was homogenised rapidly with a Hobart®

165 mixer in order to maintain a low temperature and then more accurately using a Polytron ${ }^{\circledR}(\mathrm{PT}$

1662100 Bioblock ${ }^{\circledR}$, Illkirch, France). A representative portion $(\sim 5 \mathrm{~g})$ was taken for lipid analysis

167 and $\sim 3 \mathrm{~g}$ was taken for dry weight measurements $\left(105^{\circ} \mathrm{C}\right.$ in an oven for $\left.24 \mathrm{~h}\right)$. Lipid analysis

168 was conducted on duplicates. Extraction of total lipids was done according to Folch et al.

169 (1957), with chloroform being replaced by dichloro-methane. The separation of neutral NL

170 and polar lipids PL was performed on fish samples according to the procedure described by

171 Juaneda and Roquelin (1985). The total lipids TL extracts were fractionated on silica

172 cartridges (Sep-Pack, Waters ${ }^{\circledR}$, Guyancourt, France), NL were eluted by chloroform and PL

173 by methanol. Fatty acid methyl esters (FAME) of TL were prepared by saponification and 
174 then methylation while PL FAMEs were prepared by transmethylation with sulphuric acid in

175 methanol. All FAMEs were separated by gas chromatography (Auto-system Perkin-Elmer ${ }^{\circledR}$

176 with a flame ionisation detector, BPX 70 capillary column: $25 \mathrm{~m}$ x $0.22 \mathrm{~mm}$ i.d. x $0.25 \mu \mathrm{m}$

177 film thickness; split-splitless injector, with helium as a carrier gas). The injector and detector

178 temperatures were 220 and $260^{\circ} \mathrm{C}$, respectively. The temperature of the oven was initially

$17950^{\circ} \mathrm{C}$, and then increased to $180^{\circ} \mathrm{C}$ in increments of $15^{\circ} \mathrm{C} \min ^{-1}$; here, it was maintained for 5

$180 \mathrm{~min}$, and then finally increased to $220^{\circ} \mathrm{C}$ in increments of $3^{\circ} \mathrm{C} \mathrm{min}^{-1}$. Data acquisition and

181 handling were carried out by connecting the GLC to a PE Nelson computer. Individual

182 FAMEs were identified by comparing the retention times of authentic standard mixtures. The

183 results of individual fatty acid composition were expressed as percent of total identified

184 FAME.

185 Chemical analyses of feed were performed in triplicate for each sample according to AOAC 186 (Association of Official Analytical Chemists 1984) methods: ash ( $7 \mathrm{~h}$ at $\left.550^{\circ} \mathrm{C}\right)$, crude fat

187 (Folch et al. 1957), and crude protein (Dumas method with an Elementary NA 2000 ${ }^{\circledR}$,

$188 \mathrm{~N} \times 6.25)$. FAME were extracted and analysed on total lipid fraction using the previously 189 described method.

190

191 Growth performance

192

193 Each month, 24h-starved fish ( $\mathrm{n}=40$ per experimental condition) were anaesthetised (tricaine

194 methane sulphonate MS-222; $0.1 \mathrm{~g} \mathrm{~L}^{-1}$, Sigma-Aldrich, St Quentin-Fallavier, France) and

195 individually identified using a pit-tag reader (MS-120, biolog-id, Réseaumatique, Bernay,

196 France) before measuring fresh weight $( \pm 0.1 \mathrm{~g})$, total length, standard length (i.e. notochord

197 length), height and width $( \pm 0.01 \mathrm{~cm})$. 
198 Specific growth rate SGR $\left(\%\right.$ day $\left.^{-1}\right)$ was calculated for each experimental condition using

199 Equation 1:

$$
\text { SGR }=100 \times \frac{(\text { Ln final body weight }- \text { Ln initial body weight })}{\text { number of days }}
$$

Swimming performance ( $\mathrm{U}_{\text {crit }}$ test)

\section{Experimental set-up}

Fish swimming and metabolic performances were assessed using a swim-tunnel respirometer (Loligo Systems, Tjele, Denmark), which was made of a respirometer and an external bath.

The respirometer (volume: $10 \mathrm{~L}$ ) was composed of (i) a swim chamber with a square working section (40 $\mathrm{cm}$ of length, $10 \mathrm{~cm}$ height, $10 \mathrm{~cm}$ of width) and (ii) a hydraulic system placed upstream to promote a laminar flow in the swim chamber. No correction for solid blocking

211 effects of the fish in the working section was made, since the calculated fractional error was $<$ $5 \%$ of the working section area (Webb 1975). The flow in the respirometer was generated by an electric motor with a propeller. It was calibrated before the start of experiments and the

214 speed ranged between 0 and $150 \mathrm{~cm} \mathrm{~s}^{-1}$. Temperature was kept constant by a recirculating 215 water system from the external bath (TECO TR20, Conselice, Italy). A flush pump allowed 216 water exchange between the respirometer and the external bath, in which water temperature and oxygenation were controlled.

\section{Oxygen consumption measurements}

221 Oxygen concentration in the respirometer was continuously measured during the experiments with an oxygen probe (PreSens, GmbH, Regensburg, Germany) connected to an oxymeter 
224 storage computer. The oxygen concentration was automatically adjusted according to the real225 time temperature recorded in the respirometer. $\mathrm{MO}_{2}$ was measured by intermittent-flow respirometry, based on an alternation between (i) a flushing phase (5 min) and (ii) a 227 measuring phase (20 min), during which the flush pump was turned off, preventing the inflow 228 of water from the external bath into the respirometer. The $\mathrm{MO}_{2}\left(\mathrm{mgO}_{2} \mathrm{~kg}^{-1} \mathrm{~h}^{-1}\right)$ was calculated 229 as in Vagner et al. (2008; Equation 2):

$$
\mathrm{MO}_{2 \text { meas }}=\left(\frac{\Delta[02]}{\Delta \mathrm{t}}\right) \times\left(\frac{\mathrm{V}}{\mathrm{m}}\right)
$$

231 where $\Delta\left[\mathrm{O}_{2}\right]$ is the oxygen concentration decrease $\left(\mathrm{mgO}_{2} \mathrm{~L}^{-1}\right)$ relative to the fish oxygen 232 consumption with respect to time $\Delta \mathrm{t}$ (hours), $\mathrm{V}$ the swim tunnel water volume $(10 \mathrm{~L})$ minus 233 the volume of the fish, and $m$ the fish weight $(\mathrm{kg})$.

234 For each $\mathrm{MO}_{2}$ measurement, a linear regression was adjusted (Graphical Analysis 3.4, 235 Beaverton, OR, USA) in order to determine $\Delta\left[\mathrm{O}_{2}\right] / \Delta \mathrm{t}$ from the graph plotting $\left[\mathrm{O}_{2}\right]$ versus 236 time. The regression coefficient of the linear relationship determined $\mathrm{MO}_{2}$ measurement 237 accuracy. Only those measurements with a regression coefficient above 0.9 were considered. 238 The bacterial $\mathrm{MO}_{2}$ was measured for half an hour before and after each experiment, and the 239 mean of both was subtracted from the $\mathrm{MO}_{2}$ measured.

240 As respiratory metabolism depends on the animal weight, $\mathrm{MO}_{2}$ was standardised for a $100 \mathrm{~g}$ 241 fish et al.(Vagner et al. 2008; Equation 3):

$$
\mathrm{MO}_{2 \text { cor }}=\mathrm{MO}_{2 \text { meas }} \times\left(\frac{m_{\text {meas }}}{m_{\text {cor }}}\right)^{1-A}
$$

243 where $\mathrm{MO}_{2 \mathrm{cor}}\left(\mathrm{mgO}_{2} \mathrm{~kg}^{-1} \mathrm{~h}^{-1}\right)$ is the oxygen consumption for a corrected weight $\left(m_{\text {cor }}=100 \mathrm{~g}\right)$, $244 \mathrm{MO}_{2 \text { meas }}$ is the measured $\mathrm{MO}_{2}\left(\mathrm{mgO}_{2} \mathrm{~kg}^{-1} \mathrm{~h}^{-1}\right)$ and $m_{\text {meas }}$ is the fish weight $(\mathrm{kg}) . A$ is the 245 allometric exponent describing the relation between the metabolic rate and the fish weight. $A$ 246 has never been determined for Liza aurata. Therefore, we used a value of 0.8 which was 247 previously estimated in teleosts (Schurmann and Steffensen 1994), and employed in the study 
by Vagner et al. (2008) for the flathead grey mullet Mugil cephalus, a species from the same

249 family as L. aurata (mugilidae).

Experimental protocol of the $U_{\text {crit }}$ test

252 Next, 96h-starved fish [SD group: mean weight \pm SE: $47.5 \pm 3.1$ g; mean standard length \pm $253 \mathrm{SE}: 15 \pm 0.3 \mathrm{~cm}, \mathrm{n}=12$; LD group: mean weight $\pm \mathrm{SE}: 45.1 \pm 2.1$; mean standard length $\pm \mathrm{SE}$ : $25414.6 \pm 0.2 \mathrm{~cm} ; \mathrm{n}=12]$ were randomly sampled in tanks using a net, and individually tested in 255 the swim-respirometer. This long starvation period ensured that $\mathrm{U}_{\text {crit }}$ and oxygen consumption 256 measurements were not influenced by digestion (Beamish 1964). The day before the test, they 257 were anaesthetised (MS-222; $0.1 \mathrm{~g} \mathrm{~L}^{-1}$ ) and transferred into a plastic bag (without exposing 258 gills to the air) from the indoor acclimatising tank to the swim chamber of the swimming 259 respirometer. After a short recovery period (about $5 \mathrm{~min}$ ), the water flow was stabilised at a 260 very low speed (0.5 Body Length $\left.B \mathrm{~s} \mathrm{~s}^{-1}\right)$ and a screen darkening the upstream part of the 261 swim chamber was placed in order to motivate the fish to occupy upstream positions. The fish 262 were allowed to recover at this low speed for the entire following night.

263 The day after, fish were submitted to a step-protocol involving progressive swimming speed 264 increments of $1.5 \mathrm{BL} \mathrm{s}^{-1}$ over 5 min from 0.5 to $3.5 \mathrm{BL} \mathrm{s}^{-1}$, and increments of $0.75 \mathrm{BL} \mathrm{s}^{-1}$ for 265 further increases until fish exhaustion (Brett 1964). At each swimming step, the velocity was 266 maintained for 20 min and $\mathrm{MO}_{2}$ was measured. Oxygen saturation never fell below $75 \%$ of air 267 saturation during $\mathrm{MO}_{2}$ measurements. During the phase of swimming speed increment, i.e. 268 between two consecutive swimming steps, water of the respirometer was renewed through the 269 flush pump reactivation. It allowed the oxygen saturation to return over $85 \%$ of air saturation. 270 The speed increments were repeated until fish exhaustion. Fish were considered exhausted (1) 271 when they were stuck in a C-shape on the grid placed at the rear of the swim chamber, or (2) 
272 when they were unable to swim away from this grid for more than $10 \mathrm{~s}$ of lighting

273 stimulations through the tunnel window at the rear of the swim chamber.

275 Excess post-exercise oxygen consumption

277 At the end of the $\mathrm{U}_{\text {crit }}$ test, the speed was progressively decreased to $0.5 \mathrm{BL} \mathrm{s}^{-1}$ and fish were 278 allowed to recover for $70 \mathrm{~min}$ according to a cycle of $20 \mathrm{~min}$ of measuring and $5 \mathrm{~min}$ of 279 recirculating water, i.e. $3 \mathrm{MO}_{2}$ measurements were recorded $(0.33,0.75$, and $1.17 \mathrm{~h}$ after the $280 \mathrm{U}_{\text {crit }}$ test). For each of these three measurement periods and for each fish, the excess $\mathrm{MO}_{2}$ $281\left(\mathrm{mgO}_{2} \mathrm{~kg}^{-1} \mathrm{~h}^{-1}\right)$ during the 70 min-recovery period following the test was determined by 282 integrating (Graphical Analysis vs. 3.4; Beaverton, OR, USA) the area bounded between the 283 post-test recovery $\mathrm{MO}_{2}$ curve and the pre-test $\mathrm{MO}_{2}\left(0.5 \mathrm{BL} \mathrm{s}^{-1}\right)$ measured over the entire recovery 284 period before the swimming test (Lee et al. 2003; Luna-Acosta et al. 2011). The 6 first hours 285 of the night recovery period were removed from the $\mathrm{MO}_{2}\left(0.5 \mathrm{BL} \mathrm{s}^{-1}\right)$ calculation, as fish $\mathrm{MO}_{2}$ 286 was high due to the stress linked to the fish transfer (personal observation). Routine $\mathrm{MO}_{2}$ 287 while swimming at $0.5 \mathrm{BL} \mathrm{s}^{-1}$ was employed rather than SMR, since it refers to the same and 288 constant level of swimming activity before and after the test (Lee et al. 2003; Luna-Acosta et 289 al. 2011).

291 Fish sampling after $\mathrm{U}_{\text {crit }}$ test

293 After the recovery period following the $\mathrm{U}_{\text {crit }}$ test, fish were anaesthetised (MS-222;0.1 $\mathrm{g} \mathrm{L}^{-1}$ ), 294 identified using a pit-tag reader, weighed $( \pm 0.1 \mathrm{~g})$, and measured $( \pm 0.1 \mathrm{~cm})$. The Fulton 295 index (FI) was determined using Equation 4 (Fulton 1904):

$$
\mathrm{FI}=\frac{\mathrm{W}}{\mathrm{L}^{3}}
$$


where $\mathrm{W}$ is the fish weight in $\mathrm{g}$ and $\mathrm{L}$ the total fish length in $\mathrm{cm}$.

298 Blood was sampled $(1 \mathrm{~mL})$ by caudal puncture using chilled heparinised syringes. All manipulations were performed quickly so that blood was obtained within 2 to 3 min following

300 transfer into the anaesthetic solution. Plasma was obtained by centrifugation ( $5 \mathrm{~min} ; 5000$ $301 \mathrm{rpm} ; 4^{\circ} \mathrm{C}$ ) and stored at $-80^{\circ} \mathrm{C}$ until further analyses of plasma osmolality $\left(\mathrm{mmol} \mathrm{kg}^{-1}\right.$;

302 Vapro ${ }^{\circledR}$ Vapour Pressure Osmometer 5520, Wescor, UT, USA; $\mathrm{n}=12$ per experimental 303 condition, i.e. 6 for each replicate tank per condition) in duplicate for all plasma samples. 304 Haematocrit (percentage of red blood cells in the centrifuged blood volume) was measured in 305 duplicate in capillary tubes centrifuged for $3 \mathrm{~min}$ at $4000 \mathrm{rpm}$ at $4^{\circ} \mathrm{C}$. Fish were dissected on 306 ice $\left(4^{\circ} \mathrm{C}\right)$ to collect liver for assessment of the hepato-somatic index HSI using Equation 5:

$$
\mathrm{HSI}=\frac{(\mathrm{W} \text { liver } \times 100)}{(\mathrm{W} \text { fish }-\mathrm{W} \text { liver })}
$$

308 where $\mathrm{W}_{\text {liver }}$ is the liver weight and $\mathrm{W}_{\text {fish }}$ is the fish weight.

309 Moreover, muscle was collected for lipid analysis above the lateral line in the caudal part in 310 order to obtain white muscle (Martinez 2003). It was stored in $-80^{\circ} \mathrm{C}$ under nitrogen until 311 further analysis.

315 For each fish, the following parameters were calculated: critical swimming speed $\mathrm{U}_{\text {crit, }}$ SMR, 316 AMR and AS. $\mathrm{U}_{\text {crit }}\left(\right.$ in BL s ${ }^{-1}$ ) was calculated using Equation 6 (Brett 1964):

$$
\mathrm{U}_{\mathrm{crit}}=\mathrm{U}_{\mathrm{t}} \times \frac{\mathrm{t}_{1}}{\mathrm{t}} \times \mathrm{U}_{1}
$$

318 where $\mathrm{U}_{\mathrm{t}}\left(\mathrm{BL} \mathrm{s}^{-1}\right)$ is the highest velocity maintained for an entire swimming step, $\mathrm{t}_{1}(\mathrm{~min})$ the 319 amount of time spent at the fatigue velocity, $\mathrm{t}(\mathrm{min})$ the prescribed swimming period $(20 \mathrm{~min})$, 320 and $\mathrm{U}_{1}$ the last increment velocity $\left(1.5\right.$ or $\left.0.75 \mathrm{BL} \mathrm{s}^{-1}\right)$. 
$321 \mathrm{SMR}\left(\mathrm{mgO}_{2} \mathrm{~kg}^{-1} \mathrm{~h}^{-1}\right)$ was extrapolated as the intercept (i.e. $\mathrm{MO}_{2}$ when $\mathrm{U}=0 \mathrm{BL} \mathrm{s}$; Brett 322 1964) of Equation 7:

$$
\mathrm{MO}_{2}=\operatorname{SMR} \mathrm{e}^{\mathrm{bU}}
$$

where $\mathrm{MO}_{2}$ is the oxygen consumption $\left(\mathrm{mgO}_{2} \mathrm{~kg}^{-1} \mathrm{~h}^{-1}\right), \mathrm{b}$ a constant, and $\mathrm{U}$ the swimming speed $\left(\mathrm{BL} \mathrm{s}^{-1}\right)$.

AMR $\left(\mathrm{mgO}_{2} \mathrm{~kg}^{-1} \mathrm{~h}^{-1}\right)$ was considered the highest $\mathrm{MO}_{2}$ recorded during the $\mathrm{U}_{\text {crit }}$ test.

Cardiomyocyte performance

\section{Solutions}

All chemicals were purchased from Sigma-Aldrich (St Quentin-Fallavier, France).

The isolation $\mathrm{Ca}^{2+}$-free solution: in $\mathrm{mM}$ : $\mathrm{NaCl}, 100 ; \mathrm{KCl}, 10 ; \mathrm{KH}_{2} \mathrm{PO}_{4}, 1 ; \mathrm{MgSO}_{4}, 5.4$; taurine, 50; $\alpha \mathrm{D}$-glucose, 20; HEPES, 10; EGTA, 0.1 (adjusted to $\mathrm{pH} 7.1$ using $\mathrm{KOH}$, osmolality: $300 \mathrm{mOsmol} \mathrm{L}{ }^{-1}$ ). The enzymatic digestion solution comprised collagenase (Type IA, $\left.0.36 \mathrm{mg} \mathrm{mL}^{-1}\right)$, trypsin (Type III, $\left.0.24 \mathrm{mg} \mathrm{mL}^{-1}\right)$ and BSA $\left(0.5 \mathrm{mgmL}^{-1}\right)$ added to the 339 isolation $\mathrm{Ca}^{2+}$-free solution.

340 The incubation medium $\mathrm{Ca}^{2+}$ solution: in $\mathrm{mM}$ : Glucose, $10 ; \mathrm{NaCl}, 130 ; \mathrm{KCl}, 5 ; \mathrm{MgSO}_{4}, 3$; $341 \mathrm{NaH}_{2} \mathrm{PO}_{4}, 0.5 ; \mathrm{CaCl}_{2}, 2$; HEPES, 10 (adjusted to $\mathrm{pH} 7.35$ using $\mathrm{KOH}$ ).

342 The hyperpotassic $100 \mathrm{mM} \mathrm{K}^{+}$solution $(100 \mathrm{~K})$ : in $\mathrm{mM}$ : glucose, 1; $\mathrm{NaCl}, 35 ; \mathrm{KCl}, 100$;

$343 \mathrm{MgSO}_{4}, 1.5 ; \mathrm{NaH}_{2} \mathrm{PO}_{4}, 0.4 ; \mathrm{CaCl}_{2}, 8$; HEPES, 10 (adjusted to $\mathrm{pH} 7.3$ using $\mathrm{KOH}$ ). 
347 Here, 24h-starved fish [SD group: mean weight \pm SE: $54.6 \pm 5.3$ g; mean standard length \pm 348 SE: $15.0 \pm 0.4 \mathrm{~cm}$; LD group: mean weight \pm SE: $40.8 \pm 5.3$; mean standard length \pm SE: 14.1

$349 \pm 0.5 \mathrm{~cm}]$ were randomly sampled in tanks using a net, and individually anaesthetised (MS$350222 ; 0.1 \mathrm{~g} \mathrm{~L}^{-1}$ ). The heart was rapidly excised and immersed in a $\mathrm{Ca}^{2+}$-free solution in order to 351 disrupt $\mathrm{Ca}^{2+}$-dependent cellular bonds. The atrium and bulbus arteriosus were removed. 352 Single ventricular cells were obtained by enzymatic dissociation using a protocol modified 353 from that described by Vornanen (1997) and Chatelier et al. (2006a). The ventricle was cut 354 into small pieces with scissors and immersed in $2 \mathrm{ml}$ of $\mathrm{Ca}^{2+}$-free solution containing 355 proteolytic enzymes. They were gently homogenised for $10 \mathrm{~min}$ at $20^{\circ} \mathrm{C}$. Following 356 enzymatic treatment, (1) the ventricle was transferred in a Petri dish containing $2 \mathrm{~mL}$ of fresh $357 \mathrm{Ca}^{2+}$ solution with enzymes. This was then (2) mechanically triturated for 5 min through the 358 opening of a Pasteur pipette; (3) the small pieces of ventricle not yet dissociated were 359 removed and placed in a new Petri dish containing $2 \mathrm{ml}$ of fresh $\mathrm{Ca}^{2+}$-free solution with 360 enzymes, while the supernatant was centrifuged ( $\left.5 \mathrm{~min}, 2500 \mathrm{rpm}, 4^{\circ} \mathrm{C}\right)$; and (4) the pellet 361 was gently suspended in $500 \mu \mathrm{L}$ of $\mathrm{Ca}^{2+}$-free solution without enzymes. Steps 1 to 4 were 362 repeated until all of the pieces of ventricle were dissociated (in general 3-4 times). Isolated 363 cardiomyocytes were then transferred in a new dish equipped with a glass bottom to allow 364 their fixation. Cells were progressively dropwise immersed in an incubation medium $\mathrm{Ca}^{2+}$ 365 solution containing $2 \mu \mathrm{M}$ of blebbistatin (Sigma-Aldrich, St Quentin-Fallavier, France) 366 dissolved in dimethyl sulphoxide DMSO in order to avoid cell contracture, and maintained in 367 a dark room at $20^{\circ} \mathrm{C}$ for at least $1 \mathrm{~h} 15$. 
$\mathrm{Ca}^{2+}$ fluxes were measured using the permeant form of the fluorescent dye FLUO-4 (FLUO-4

372 AM acetoxy-methyl-ester, Invitrogen, Saint-Aubin, France), dissolved in DMSO. The probe 373 was added $(2 \mu \mathrm{M})$ to the physiological medium in the dish in which cells were fixed. After $1 \mathrm{~h}$ 374 of loading in a dark room, cells were carefully washed with the incubation medium. 375 Fluorescence was recorded using a microscope LEICA DMI6000B (Saint-Jorioz, France) 376 equipped with a FLUO Oligochrome lamp and a camera ORCA-R2. The acquisition software 377 was Morpho Strider (Explora-Nova, La Rochelle, France). Excitation of FLUO-4 was set at $494 \mathrm{~nm}$, and the fluorescence emission was collected through a dichroic filter at $505 \mathrm{~nm}$.

379 Cells were individually stimulated with $100 \mathrm{~K}$ solution in order to change the potassium 380 equilibrium potential, resulting in a decrease of the inward rectifier potassium current which 381 is known to stabilise the resting membrane potential (Galli et al. 2009and). Thus, 382 cardiomyocytes exposed to $100 \mathrm{~K}$ solution were depolarised, inducing global $\mathrm{Ca}^{2+}$ fluxes, 383 possibly via the activation of L-type $\mathrm{Ca}^{2+}$ channels and $\mathrm{Na}^{+} / \mathrm{Ca}^{2+}$ exchangers. Cells $(\mathrm{n}=14$ for SD group and $\mathrm{n}=16$ for LD group) were locally perfused with incubation medium via a small delivery tube positioned near the cell (less than $1 \mathrm{~mm}$ ). This solution was rapidly exchanged 386 for 100K (one drop, $20 \mu \mathrm{L}$ ). Then, stimulation of the cardiomyocytes was stopped by the fast 387 change of the $100 \mathrm{~K}$ solution by the incubation medium.

388 Ryanodin solution (RYA; $1 \mathrm{mM}$; Ascent Scientific, Bristol, UK) was used to evaluate calcium 389 mobilization from the sarcoplasmic reticulum (SR) when stimulation occurs. Ryanodin (10 $390 \mu \mathrm{M}$ ) binds to the ryanodin receptor located on the SR, and locks the SR- $\mathrm{Ca}^{2+}$ release channel 391 in the open state, rendering it unable to contribute to $\mathrm{Ca}^{2+}$ transient (Rousseau et al. 1987). As 392 a consequence, by subtracting the concentration of $\mathrm{Ca}^{2+}$ measured in cells stimulated with 393 RYA to that measured with $100 \mathrm{~K}$, the $\mathrm{Ca}^{2+}$ concentration released by SR can be estimated.

394 Adrenaline solution (AD; $10 \mu \mathrm{M}$, Sigma-Aldrich; St Quentin-Fallavier, France) was used to 395 investigate the effects of $\beta$-adrenergic receptors upon the cellular calcium responses. As a $\beta_{2^{-}}$ 
type adrenergic receptor agonist, $\mathrm{AD}$ increased the density of the L-type calcium current by

397 elevating the open-probability of the L-type calcium channels (Vornanen 1997; 1998; Hove398 Madsen et al. 1998) after phosphorylation (Shiels et al. 1998). This is supposed to increase the 399 force of contraction. AD also stimulates the $\mathrm{Ca}^{2+}$ ATPase pump of the $\mathrm{RS}$, inducing the $\mathrm{Ca}^{2+}$ 400 re-pumping after the contraction phase, and then accelerating the relaxation. To perform these 401 experiments, fish cells (RYA: $n=16$ for SD group and $n=13$ for LD group; AD: $n=13$ for 402 SD group and $n=10$ for LD group) were bathed in the stimulating solution (RYA or AD) 403 diluted in incubation medium for $30 \mathrm{~s}$ (one drop, $20 \mu \mathrm{L}$ ). This allowed the fixation of RYA and $\mathrm{AD}$ to the SR ryanodin and beta-adrenergic receptors respectively. Cells were then briefly perfused with the stimulating solution (RYA or AD) diluted in $100 \mathrm{~K}$ in order to stimulate 406 intracellular $\mathrm{Ca}^{2+}$ release.

407 All perfusions were rapid, in order to prevent excessive stimulation and possible contracture 408 followed by cell death, and a maximum of two cells were stimulated in each dish.

409 For each stimulated cell, the fluorescence was normalised (F/F0), where F0 was the mean of 410 the data points recorded during the first $30 \mathrm{~s}$ in which cells were perfused with incubation 411 medium. Then, for each cell, the maximal amplitude of calcium mobilised, the time to reach 412 the peak $(t p)$, and the time to reach $50 \%$ relaxation (decay $50 \%$, tr) were measured (Imbert413 Auvray et al. 2013).

414 All the analyses performed in this study are summarized in Table 2.

416 Statistical analysis

418 The data are presented as mean \pm standard error (SE). All statistical analyses were performed 419 with Statistica ${ }^{\circledR}$ software vs.7 (StatSoft, Maison-Alfort, France). Concerning growth during 420 the experimental period, slopes of regression curves were determined for each fish. The effect 
421 of diet on these slopes, as well as on SGR, $\mathrm{U}_{\text {crit, }}$ SMR, AMR, plasma haematocrit, plasma

422 osmolality, HSI, FI, and the $\mathrm{MO}_{2}$ excess during the recovery period integral was tested using 423 a one-way ANOVA with $\mathrm{n}=$ the number of fish replicates for each dietary condition.

424 Moreover, the effect of diet on each of the three successive measurements of $\mathrm{MO}_{2} \mathrm{r}(\mathrm{t})$ was 425 tested using a repeated-measure ANOVA with the three successive measurements used as the 426 within effect. Concerning cardiomyocyte performance, the effect of diet on the amplitude, $t p$, 427 and $t r$ recorded when cells were stimulated with $100 \mathrm{~K}$, RYA, or AD was tested using a one428 way ANOVA with $n=$ the number of cell replicates for each dietary condition. Prior to 429 ANOVA analyses, normality distribution and homeodasticity were controlled using 430 Kolmogorov-Smirnov and the Levene test, respectively. Differences were considered 431 significant when $\alpha<0.05$.

\section{Results}

All groups of fish appeared healthy and survival was close to $100 \%$ at the end of the experiment.

Fatty acid composition in fish

440 No significant difference of TL, NL or PL content was found between the two dietary groups 441 of fish (Table 3). As expected, fish fatty acid composition reflected that of the diet, and EPA 442 and DHA were preferentially incorporated in phospholipids (PL) for both groups (One-way ANOVA: EPA: $P<0.001 ; F_{1,86}=86.75$; DHA: $\left.P<0.001 ; F_{1,86}=20.8\right)$ (Table 3 ). In both lipid classes (PL and NL), the sum of saturated fatty acids ( $\sum$ SFA) was $15 \%$ 445 higher in the group fed the standard n-3 HUFA content diet (SD group) than in that fed the 
446 low n-3 HUFA content diet (LD group; Table 3). In NL, this difference reflected that of all 447 SFA tested (14:0, 16:0, 18:0, and 20:0), while in PL, this mostly reflected the difference in $448 \quad 14: 0$ and 16:0 FA content, as the 18:0 and 20:0 FA contents were similarly incorporated in 449 both groups. $\sum$ monounsaturated fatty acids MUFA levels were also $15 \%$ higher in SD than in 450 LD fish, and reflected a difference in both 16:1 and 18:1 in the two dietary groups (Table 3). higher in the LD group than in the SD group, for both PL and NL. However, arachidonic acid (ARA; 20:4n-6) was similarly present in the PL of both groups $(P>0.05)$, but was significantly more incorporated (30\%) in the NL of SD than in that of LD groups (Table 3). present in the NL and PL of the SD group than in the LD group $(P<0.05$; Table 3$)$. Only the 18:3n-3 FA content was almost 2 -fold lower in the SD than LD group. The $n-3 / n-6$ ratio was only above one in the PL of the SD group, whereas it was below one in the PL of the LD group, as well as in the NL of the two dietary groups (Table 3). similar in the PL of fish fed the SD and LD diet. Finally, the ARA/EPA ratio was significantly higher in the NL of the LD group, but was not different in the PL, regardless of the dietary group investigated (Table 3).

Growth performances and body condition

The SGR of the SD group was significantly higher (25\%) than that of the LD group (Table 4). In addition, fish from the SD group exhibited a significantly higher increase in standard length throughout the entire experiment than fish from the LD group $\left(P<0.001 ; F_{2,72}=24.01\right)$.

470 However, the hepatosomatic index (HSI) and FI were not affected by $\operatorname{diet}(P>0.05$; Table 4$)$. 
472 Swimming performance, energetics and blood parameters

474 As expected, $\mathrm{MO}_{2}$ increased exponentially with swimming speed for both the SD and LD 475 groups (Fig. 1; e.g. Brett 1964; Webb 1975; Vagner et al. 2008; Milinkovitch et al. 2012).

476 Results concerning the effect of HUFA dietary content on $\mathrm{U}_{\text {crit, }}$ SMR, AMR, AS, haematocrit, 477 and plasma osmolality, are summarised in the Table $3 . \mathrm{U}_{\text {crit }}$ was not affected by diet $(P>$ 478 0.05). On the contrary, both AMR and AS measured in the LD group were more than two-fold 479 lower than in the SD group $(P<0.001)$. Moreover, this was associated with an increase of 480 more than $20 \%$ of haematocrit and $7 \%$ of plasma osmolality $(P<0.05)$.

Excess Post-exercise Oxygen Consumption

484 The excess $\mathrm{MO}_{2}$ measured during the post-exercise period at low speeds was found to be 485 dependent on $\operatorname{diet}(P<0.05$; Fig. 2$)$, and was more than $45 \%$ higher in the SD than in the LD 486 group.

Cardiomyocytes performances

490 Variables representative of the kinetics of calcium fluxes (peak amplitude, the time to reach 491 the peak, $t p$, and the time to reach $50 \%$ relaxation, $t r$ ), in response to stimulation 492 (hyperpotassic solution 100K, ryanodin RYA, or adrenaline AD) are presented in Figs 3a, b, 493 and c for each dietary group. Whatever stimulator was used, there was no effect of diet 494 reported for these variables $(\mathrm{P}>0.05)$. Moreover, no significant effect of the stimulator, 495 neither on peak amplitude nor on $t r$, was observed $(\mathrm{P}>0.05)$. However, $t p$ was significantly 
496

497

498

499

500

501

502

503

504

505

506

507

508

509

510

511

512

513

514

515

516

517

518

519

520

reduced by more than $50 \%$ in cells stimulated with RYA compared to those stimulated with $100 \mathrm{~K}$ and $\mathrm{AD}(\mathrm{P}<0.01)$.

\section{Discussion}

This study is the first to measure the effect of a reduction in n-3 HUFA dietary content, as expected with global change, on physiological performances of the golden grey mullet, a species of high ecological importance in European coastal areas. The results showed that the low n-3 HUFA dietary content reduced growth rate and the aerobic capacity of Liza aurata at $20^{\circ} \mathrm{C}$. This diet also induced higher levels of haematocrit and plasma osmolality. However, this diet did not impact SMR or $\mathrm{U}_{\text {crit }}$.

The n-3 HUFA content of the LD diet was about six-fold lower than that of the SD diet, suggesting a deficiency of n-3 HUFA in that diet. The immediate consequence of feeding with both of these diets was a modification of the n-3 HUFA membranous content in fish. As expected, the cell membrane bilayer reflected the HUFA dietary content in both groups (Linares and Henderson 1991; Jobling 2001), as (1) fish fed the LD diet presented a significantly lower n-3 HUFA, including EPA and DHA, content than those fed the SD diet, and (2) both of these fatty acids were preferentially incorporated in PL rather than NL in both dietary groups, indicating their integration in cell membranes (Linares and Henderson 1991).

As said earlier, the LD diet induced a significantly lower growth rate in L. aurata over the five month experimental period. This result confirms the importance of dietary HUFA, and especially EPA and DHA, for normal growth, as observed in other species such as juvenile flounder (Kim and Lee 2004), cod (Lee and Cho 2009), yellow croaker (Zuo et al. 2012), or juvenile cobia (Liu et al. 2007). This lower growth rate did not appear to be due to a lower food intake in the LD group, as even though the feed intake was not accurately 
monitored during our experiment for technical reasons, visual daily observations performed during the meal time allowed us to hypothesise that SD and LD fish ate similarly. In addition to their lower growth rate, fish from the LD group exhibited a lower increase in standard length from the beginning to the end of the experiment (results not shown). This resulted in a similar body condition as shown by FI and HSI measured in both dietary groups (Equation 4). While it reduced growth rate, the low n-3 HUFA diet did not impair the ability of fish to maintain vital functions such as ventilation and osmoregulation. This was shown by the similar SMR values measured in both dietary groups (Fry 1971), which were close to that previously reported in another mugilid species (Vagner et al. 2008). Moreover, the n-3 HUFA dietary content did not significantly affect $\mathrm{U}_{\text {crit }}$ at $20^{\circ} \mathrm{C}$, as the $\mathrm{LD}$ group achieved the same $\mathrm{U}_{\text {crit }}$ as the SD group. As suggested by previous authors, sustained swimming performances may not only depend on the n-3 HUFA metabolism, but also on other FA metabolism as an energy source, such as MUFA or SFA (Chatelier et al. 2006b; Regan et al. 2010). Despite this similar $U_{\text {crit }}$ measurement in both groups, the lower n-3 HUFA diet significantly reduced AMR and AMS. This indicates that LD fish achieved the same $\mathrm{U}_{\text {crit }}$ as SD fish but with a significantly lower metabolic cost. This is in contrast with results obtained in previous studies, which showed that lower AMR and AMS were both linked to lower swimming performances (Chatelier et al. 2006b). Our original results could be partially explained by the marked accumulation of n-6 FA in both the NL and PL of fish fed the LD diet, which may have compensated for the lower levels of n-3 FA in that group. In particular, the high levels of linoleic and oleic acids have been shown to be positively correlated with $\mathrm{U}_{\text {crit }}$ performance in Atlantic salmon (McKenzie et al. 1998) and sea bass (Chatelier et al. 2006b). Linoleic acid $(18: 2 n-6)$ has also been shown to increase carnitine palmitoyl transferase activity, which may improve the aerobic metabolism of fatty acids in red muscle (Sidell and Driedzic 1985 ; Egginton 1996). 
While LD fish performed the same $\mathrm{U}_{\text {crit }}$ as SD fish, the decrease in AMS measured in

547 that group suggests that the low n-3 HUFA diet could reduce the capacity for oxygen

548 allocation toward energy-demanding activities such as foraging, growth and digestion (Fry

549 1971). This result is in accordance with the lower growth rate found in that group.

550 The lower AMS caused by the low n-3 HUFA dietary content could reflect a lower capacity 551 of oxygen transport in that group. The n-3 HUFA dietary content may have modified the 552 membrane lipid composition of mitochondria, and consequently reduced the respiratory rate 553 of mitochondria, as suggested in rainbow trout by Guderley et al. (2008). These authors 554 reported a higher respiratory rate in the mitochondria of rainbow trout fed a diet enriched in 555 EPA and DHA compared to fish fed a diet poorer in those FA, and suggested that the level of 556 these specific FA would be statistically correlated with mitochondria capacity. Another 557 hypothesis to explain the higher aerobic metabolism in fish fed the enriched n-3 HUFA diet 558 would be an increasing number of mitochondria as the n-3 HUFA dietary content increased, 559 as previously demonstrated by Kjaer et al. (2008) in the liver of Atlantic salmon fed a diet that 560 was rich in EPA. This would induce the higher production of ATP. In other vertebrates such 561 as several mammals and bird species, a high positive correlation between the molecular 562 activity (ATP $\mathrm{min}^{-1}$ ) of individual $\mathrm{Na}^{+} \mathrm{K}^{+}$ATPase units and the content of DHA in the 563 surrounding membranes bilayer was found, suggesting a higher metabolic activity in tissue 564 (Turner et al. 2003). However, one consequence of the higher aerobic metabolism measured 565 in fish fed the SD diet would be an increasing lipid peroxidation in membranes, as 566 phospholipids are particularly vulnerable to oxidation (Crockett 2008). Lipid peroxidation 567 represents a distinct set of oxidations initiated by reactive oxygen species that possess 568 sufficient energy to remove a hydrogen atom from a methylene group within the parent lipid 569 (Girotti 1985). Lipid peroxidation in biological membranes may be deleterious because of 570 influences on membrane physical properties likely to affect protein function (Crockett 2008). 
571 Contrary to the present study, previous works have reported that a high n-3 HUFA dietary

572 content reduced AMR and AMS, suggesting that aerobic metabolism in fish is primarily 573 fuelled by FA oxidation, with MUFA being preferred over SFAs which, in turn, are preferred 574 over HUFA as substrates (Henderson and Sargent 1985 ; Egginton 1996 ; McKenzie 2001; 575 Chatelier et al. 2006b). Indeed, MUFA and SFA are mostly incorporated in triacylglycerols 576 which constitute lipid reserve used as fuels by tissues, while HUFA are mainly used as 577 structural lipids incorporated in biological membranes or as precursors of eicosanoids (for review, see Sargent et al. 2002). However, while there is no doubt that dietary and tissue FA exert profound effects on metabolic and cardio-respiratory physiology of vertebrates, the explanation of such contrasting results is not known, and further studies are required to 581 understand the mechanisms responsible for these effects.

582 The lower aerobic metabolic rate induced by the low n-3 HUFA dietary content does not appear to be due to a lower capacity of oxygen transport by blood. Indeed, the lower AMS measured in the LD group was associated with a higher haematocrit at the end of the $U_{\text {crit }}$ test, indicating higher red cells production, and a consequently higher capacity of oxygen transport 586 in that group. This could have contributed to maintaining swimming at the same velocity, as 587 in the SD group (Thorarensen et al. 1993). This higher haematocrit could reflect the need for 588 those fish to increase their oxygen supply in order to survive in a stressful environment, since 589 a higher haematocrit is one of the indicators of fish health, and may reflect a stress response in 590 fish. This has already been reported in fish submitted to crowding stress (Trenzado, Morales 591 and de la Higuera 2006; 2009) or hypoxic conditions (Zambonino et al. 2013). This stress 592 response is corroborated by (1) the higher plasma osmolality, (2) the lower AMS and AMR, 593 and (3) the lower growth rate measured in the LD group. Indeed, after a primary response 594 during which activation of the brain-sympathetic-chromaffin cell axis and the brain-pituary 595 inter-renal axis, resulting in the release of stress hormones such as cortisol (not measured in 
596 the present study), stress response is characterised by a secondary response during which

597 these hormones have an effect at blood and tissues levels, including a disturbance of ionic and 598 osmotic balance, and by a third response characterised by the inhibition of growth and 599 changes in metabolic rate (Schreck 1982; Barton and Iwama 1991; Wendelaar Bonga 1997; 600 Mommsen et al. 1999).

601 The higher haematocrit measured in the LD group could also be due to alterations of 602 the mitochondrial membranes by the low n-3 HUFA dietary content, as suggested in rainbow 603 trout by Guderley et al. (2008). This would have led to an alteration of the conformation and activity of the embedded protein, reducing the capacity of oxygen transport across the 605 membrane and toward mitochondria. This would have resulted in a higher oxygen demand 606 from mitochondria, and consequently, to increasing red cell production as a strategy to cope 607 with elevated energy demand. In addition to indicating a secondary stress response, the higher osmolality measured 609 at the end of the $U_{\text {crit }}$ test in the LD group could also suggest a higher ventilation rate (not 610 measured) developed in order to increase oxygen supply during the effort. It is well described 611 that swimming leads to an improving gas exchange at the gills through ventilation rate, and 612 that the consequence is passive ion movement across the gills. In seawater fish, the ion 613 movement is from the water to the animal, and the consequence is dehydration. Through an 614 increasing ventilation rate, fish would have an increased passive ion movement from water to 615 the gills, increasing osmolality in their system. This ion movement is normally compensated 616 by water absorption through the intestinal membrane, as well as by ion excretion through the 617 sodium-chloride channels of the gill membrane in order to maintain the osmotic balance. 618 However, as this ion excretion represents an energetic cost because it is against the 619 concentration gradient, fish fed the low n-3 HUFA content diet may have spared that cost in 620 order to save energy, as their aerobic capacity was reduced. 
While fish fed the low n-3 HUFA diet displayed a lower capacity for oxygen transport,

622 they did not show any lower cardiomyocyte performance, measured by the $\mathrm{Ca}^{2+}$ fluxes in response to different chemical stimulations, compared to the group fed the standard n-3

624 HUFA diet. The measure of similar cardiomyocyte performances is in accordance with the measurements of similar $U_{\text {crit }}$ values in both dietary groups, as several studies have argued that $\mathrm{U}_{\text {crit }}$ in active teleosts may be primarily limited by aerobic myocardial performance (Farrell 2002; Claireaux et al. 2005). These results could suggest that modification of the membranous n-3 HUFA content in response to diet did not impact the functionality of those calcium channels embedded in cardiomyocyte membranes or the SR membranes of cardiomyocytes. However, the cardiomyocyte lipid composition was not measured in the present study. While our results showed that the white muscle FA composition reflected that of the diet, we do not know how it varied in heart tissue. Indeed, recent studies showed that the FA composition of the different fish tissues (liver, heart, kidney, intestine, liver, eyes...) does not respond in the same way to diet (Benedito-Palos et al. 2010; Böhm et al. 2014). The absence of any significant differences between dietary groups could also be due to the experimental temperature used $\left(20^{\circ} \mathrm{C}\right)$, as many previous studies have shown differences in the thermal sensitivity of the mechanisms involved in calcium regulation in fish cardiomyocytes. For example, the effects of adrenaline were mainly observed in coldacclimated teleosts (perch: Tirri and Ripatti, 1982; Tirri and Lehto, 1984; rainbow trout: Graham and Farrell 1989; Keen et al. 1994). Moreover, SR- $\mathrm{Ca}^{2+}$ loading and mobilisation has been shown to depend on species and thermal acclimation (Imbert-Auvray et al. 2013).

At $20^{\circ} \mathrm{C}, \mathrm{Ca}^{2+}$ release did not seem to depend on the SR in Liza aurata, but mainly on the calcium L-type channel located on the cytoplasmic membrane, as similar amplitudes of $\mathrm{Ca}^{2+}$ release in response to the stimulation with ryanodine added to $100 \mathrm{~K}$ or $100 \mathrm{~K}$ alone were measured. This is in accordance with other authors who showed that $\mathrm{Ca}^{2+}$ release from 
646 the SR was rather limited in the ectothermic vertebrate heart, such as those of fish (Shiels et 647 al. 2004) and amphibians (Fischmeister and Horackova 1983; Nabauer et al. 1989). The lower anaerobic metabolism measured in fish fed the low n-3 HUFA diet is

649 coincident with their lower swimming cost measured during the $U_{\text {crit }}$ test, and indicated that 650 these fish recovered very quickly. Their lower anaerobic capacity was confirmed by their 651 lower excess $\mathrm{MO}_{2}$ measured during the 70 min recovery period (Lee et al. 2003; Luna-Acosta 652 et al. 2011; Zhao et al. 2012). This lower excess $\mathrm{MO}_{2}$ reflects a lower quantity of oxygen 653 required to restore tissue and cellular stores of oxygen and high-energy phosphates, 654 biochemical imbalances in metabolites such as lactate and glycogen, and other functions such 655 as ionic and osmotic balance in this group (Lee et al. 2003). The higher haematocrit content 656 measured in that group could have contributed to this better recovery.

657 To conclude, the results of the present study show that a reduction in n-3 HUFA 658 availability in diet until $0.2 \% \mathrm{EPA}+\mathrm{DHA}$ (on dry matter basis) would reduce the growth rate 659 as well as the aerobic capacity of Liza aurata at $20^{\circ} \mathrm{C}$. As stated earlier, aerobic capacity 660 represents the energy available to perform energy-demanding activities, and the excess energy 661 will be allocated to growth once other activities have been allocated (Fry 1971). The reduction 662 of aerobic metabolism by the low n-3 HUFA content diet suggests that fish may have to save 663 energy by modifying the proportion of energy allocated to energy-demanding activities, such 664 as digestion or feeding. This also suggests that the growth rate will consequently be reduced. 665 This long-term strategy of energy allocation could explain the decreasing growth rate 666 measured when fish were given the deficient diet over the 5 month experimental period. In 667 addition to a lower growth rate and aerobic metabolism, the lower n-3 HUFA diet induced 668 higher levels of haematocrit and plasma osmolality, which are all indicators of a stress 669 response at the second and third levels in that group. 
670 However, our results showed that the lower n-3 HUFA diet (or higher MUFA and linoleic 671 acids) caused a massive change in swimming efficiency and recovery capacity that should 672 bring ecological advantages in the capacity of fish to migrate or avoid predators. This is of 673 particular importance to L. aurata which is a migratory species that reproduces at sea and uses 674 coastal areas to grow and to feed.

675 The higher swimming efficiency caused by a deficient n-3 HUFA dietary content would allow 676 fish to increase their mobility and distribution, thus increasing the range over which feeding 677 and reproduction occurs. These changes in turn would compensate for the reduction of growth 678 and aerobic metabolism induced by diet.

679

680

\section{Acknowledgments}

681

682

This work was supported by the Action Initiative of the University of La Rochelle to Marie 683 Vagner (post-doctoral fellowship). The authors are very grateful to Andrea Satta and Fabio Antagnarelli for supplying fish; to Michel Prineau for his technical help; and to David Akbar and Marie Durollet for their help with cellular analysis and microscopy.

686

687

\section{Conflict of interest}

688

689 The authors have no conflict of interest to declare and note that the sponsors of the issue had 690 no role in the study design, data collection and analysis, decision to publish, or preparation of 691 the manuscript

692

693

\section{References}

694 
AOAC Association of Official Analytical Chemists (1984) Official methods of analysis.

696 Association of analytical chemists 1: pp 1141.

697 Barton BA, Iwama GK (1991) Physiological changes in fish from stress in aquaculture with

698 emphasis on the response and effects of corticosteroids. Ann Rev Fish Dis 1:3-26

699 Beamish FWH (1964) Influence of starvation on standard and routine oxygen consumption. T

700 Am Fish Soc 93:103-107. doi: 10.1577/1548-8659(1964)93[103:IOSOSA]2.0.CO;2

701 Bell JG, Ashton I, Secombes CJ, et al. (1996) Dietary lipid affects phospholipid fatty acid 702 compositions, eicosanoid production and immune function in Atlantic salmon (Salmo salar).

703 Prostag, Leukotr ESS 54:173-182. doi: 10.1016/S0952-3278(96)90013-7

704 Benedito-Palos L, Navarro JC, Kaushik S, Perez-Sanchez J (2010) Tissue-specific robustness 705 of fatty acid signatures in cultured gilthead sea bream (Sparus aurata L.) fed practical diets 706 with a combined high replacement of fish meal and fish oil. J Anim Sci 88:1759-1770. doi: 707 $10.2527 /$ jas.2009-2564

708 Béthoux J, Gentili B, Tailliez D (1998) Warming and freshwater budget change in the 709 Mediterranean since the 1940s, their possible relation to the greenhouse effect. Geophys Res 710 Lett 25:1023-1026. doi: 10.1029/98GL00724

711 Böhm M, Schultz S, Koussoroplis A-M, Kainz MJ (2014) Tissue-specific fatty acids response 712 to different diets in common carp (Cyprinus carpio L.). PLoS ONE 9:e94759. doi: 713 10.1371/journal.pone.0094759

714 Brett JR (1964) The respiratory metabolism and swimming performance of young sockeye 715 salmon. J Fish Res Board Can 21:1183-226

716 Chatelier A (2006a) Associations between tissue fatty acid composition and physiological 717 traits of performance and metabolism in the seabass (Dicentrarchus labrax). J Exp Biol 718 209:3429-3439. doi: 10.1242/jeb.02347 
719 Chatelier A, Imbert N, Infante JLZ, et al. (2006b) Effects of oleic acid on the high threshold 720 barium current in seabass Dicentrarchus labrax ventricular myocytes. J Exp Biol 209:4033721 4039. doi: 10.1242/jeb.02470

722 Chen Y-C (2012) The biomass and total lipid content and composition of twelve species of 723 marine diatoms cultured under various environments. Food Chem 131:211-219. doi: 724 10.1016/j.foodchem.2011.08.062

725 Claireaux G, Lefrancois C (2007) Linking environmental variability and fish performance: 726 integration through the concept of scope for activity. Philos Trans R Soc B Biol Sci 362:2031-2041. doi: 10.1098/rstb.2007.2099

Claireaux G, McKenzie DJ, Genge AG, Chatelier A, Aubin J, Farrell T (2005) Linking swimming performance cardiac pumping ability and cardiac anatomy in rainbow trout. J Exp $730 \quad$ Biol 208: 1775-1784

731 Crawford MA, Broadhurst CL (2012) The role of docosahexaenoic and the marine food web 732 as determinants of evolution and hominid brain development: the challenge for human sustainability. Nutr Health 21:17-39. doi: 10.1177/0260106012437550

734 Crockett EL (2008) The cold but not hard fats in ectotherms: consequences of lipid 735 restructuring on susceptibility of biological membranes to peroxidation, a review. J Comp 736 Physiol B 178:795-809. doi: 10.1007/s00360-008-0275-7

737 Domenici P, Herbert NA, Lefrançois C, Steffensen JF, McKenzie DJ (2013) The effect of 738 hypoxia on fish swimming performance and behaviour. Swimming Physiology of Fish 739 Springer Berlin Heidelberg, pp 129-159

740 Dosanjh BS, Higgs DA, McKenzie DJ, Randall DJ, Eales JG, Rowshandeli N, Rowshandeli 741 M, Deacon G (1998) Influence of dietary blends of menhaden oil and canola oil on growth 742 muscle lipid composition and thyroidal status of Atlantic salmon (Salmo salar) in sea water.

$743 \quad$ Fish Physiol Biochem 19:123-134 
744 Egginton S (1996) Effect of temperature on optimal substrate for $\beta$-oxidation. J Fish Biol $745 \quad 49: 753-758$

746 Farrell AP (2002) Cardiorespiratory performance in salmonids during exercise at high 747 temperature: insights into cardiovascular design limitations in fishes. Comp Biochem Physiol 748 A $132: 797-810$

749 Fischmeister R, Horackova M (1983) Variation of intracellular $\mathrm{Ca}^{2+}$ following $\mathrm{Ca}^{2+}$ current in 750 heart A theoretical study of ionic diffusion inside a cylindrical cell. Biophys J 41:341-348

751 Folch J, Lees M, Sloane-Stanley GH (1957) A simple method for the isolation and 752 purification of total lipids from animal tissues. J Biol Chem 226:497-509

753 Fry FE (1947) Effects of the environment on animal activity. University of Toronto Studies 754 Biological Series 55 Publication of the Ontario Fisheries Research Laboratory 68:1-62

755 Fry FE (1971) The effect of environmental factors on the physiology of fish In: Hoar \& 756 Randall Fish physiology VI, Academic Press, NY, S Francisco, London, pp 1-98

757 Fulton TW (1904) The rate of growth of fishes $22^{\text {nd }}$ Annual Report of the Fishery Board of 758 Scotland 1904(3):141-241

759 Galli G, Shiels H, Brill R (2009) Temperature sensitivity of cardiac function in pelagic fishes 760 with different vertical mobilities: yellowfin tuna (Thunnus albacares) big eye tuna (T. obesus) 761 mahi mahi (Coryphae nahippurus) and swordfish (Xiphias gladius). Physiol Biochem Zool $762 \quad 82: 280-290$

763 Girotti AW (1985) Mechanisms of lipid peroxidation. J Free Rad Biol Med 1:87-95

764 Glencross BD (2009) Exploring the nutritional demand for essential fatty acids by aquaculture 765 species. Reviews in Aquaculture 1:71-124

766 Goffart A, Hecq JH, Legendre L (2002) Changes in the development of the winter-spring 767 phytoplankton bloom in the Bay of Calvi (NW Mediterranean) over the last two decades: a 768 response to changing climate? Mar Ecol Prog Ser 236: 45-60 
769 Gomez F, Souissi S (2008) The impact of the 2003 summer heat wave and the 2005 late cold

770

771

772

773

774

775

776

777

778

779 New York, pp 377

780 Gypens N, Lacroix G, Lancelot C (2007) Causes of variability in diatom and Phaeocystis

781 blooms in Belgian coastal waters between 1989 and 2003: A model study. J Sea Res 57:19-

782 35. doi: $10.1016 /$ j.seares.2006.07.004

783 Henderson RJ, Sargent JR (1985) Chain-length specificities of mitochondrial and peroxisomal

$784 \beta$-oxidation of fatty acids in livers of rainbow trout (Salmo gairdneri). Comp Biochem

785 Physiol B 82:79-85

786 Hove-Madsen L, Llach A, Tort L (1998) Quantification of $\mathrm{Ca}^{2+}$ uptake in the sarcoplasmic

787 reticulum of trout ventricular myocytes. Am J Physiol 275:2070-2080

788 Imbert-Auvray N, Mercier C, Bois P (2013) Sarcoplasmic reticulum: a key factor in cardiac

789 contractility of sea bass Dicentrarchus labrax and common sole Solea solea during thermal

790 acclimations. J Comp Physiol B 183(4):477-89

791 Jain K E Birtwell I K Farrell A P (1998) Repeat swimming performance of mature sockeye

792 salmon following a brief recovery period: a proposed measure of fish health and water quality

793 Can J Zool 76:1488-1496 
794 Jobling M (2001) Nutrient partitioning and the influence of feed composition on body 795 composition, In: Houlihan D, Boujard Jobling M (Eds) Food Intake in Fish. Blackwell 796 Scientific, Oxford UK, pp 354-375

797 Juaneda P, Roquelin G (1985) Rapid and convenient separation of phospholipids and non798 phosphorus lipids from rat heart using silica cartridges. Lipids 20:40-41

799 Kalogeropoulos N, Alexis MN, Henderson RJ (1992) Effects of dietary soybean and cod-liver 800 oil levels on growth and body composition of gilthead bream (Sparus aurata). Aquaculture $801 \quad 104: 293-308$

802 Kates K, Volcani BE (1966) Lipid components of diatoms. Biochem Biophys Acta 116:264$803 \quad 278$

804 Keen JE, Viazon DM, Farrell AP, Tibbits GF (1994) Effect of temperature acclimation on the 805 ryanodine sensitivity of the trout myocardium. J Comp Physiol B 164:438-443

806 Kim K-D, Lee S-M (2004) Requirement of dietary n-3 highly unsaturated fatty acids for 807 juvenile flounder (Paralichthys olivaceus). Aquaculture 229:315-323. doi: 10.1016/S0044808 8486(03)00356-9

809 Kjaer MA, Vegusdal A, Gjoen T, Rustan AC, Todorcevic M, Ruyter B (2008) Effect of 810 rapeseed oil and dietary n-3 fatty acids on triacylglycerol synthesis and secretion in Atlantic 811 salmon hepatocytes. Biochem Biophys Acta 1781:112-122

812 Lee SM, Cho SH (2009) Influences of dietary fatty acid profile on growth body composition 813 and blood chemistry in juvenile fat cod (Hexagrammo usotakii Jordan and Starks). Aquacult 814 Nutr 15:19-28

815 Lee CG Farrell AP, Lotto A, Hinch SG, Healey MC (2003) Excess post-exercise oxygen 816 consumption in adult sockeye (Oncorhynchus nerka) and coho (O. kisutch) salmon following 817 critical speed swimming. J Exp Biol 206:3253-3260. doi: 10.1242/jeb.00548 
818 Lee S-M, Lee JH, Kim K-D (2003) Effect of dietary essential fatty acids on growth, body

819 composition and blood chemistry of juvenile starry flounder (Platichthys stellatus).

820 Aquaculture 225:269-281. doi: 10.1016/S0044-8486(03)00295-3

821 Lenhardt M, Jarić I, Cakić P, et al. (2009) Seasonal changes in condition, hepatosomatic index

822 and parasitism in sterlet (Acipenser ruthenus L.). Turk J Vet Anim Sci 33:

823 Leu E, Wängberg SA, Wulff A, Falk-Petersen S, Ørbæk JB, Hessen DO (2006) Effects of

824 changes in ambient PAR and UV radiation on the nutritional quality of an Arctic diatom

825 (Thalassiosira antarctica var borealis). J Exp Mar Biol Ecol 337(1):65-81

826 Linares F, Henderson RJ (1991) Incorporation of 14C-labelled polyunsaturated fatty acids by

827 juvenile turbot Scophtalmus maximus (L) in vivo. J Fish Biol 38:335-347

828 Liu XW, Tan BP, Mai KS, Ai QH, Zhou QC (2007) Effects of dietary highly unsaturated fatty

829 acids on growth and fatty acid composition of juvenile cobia (Rachycentron Canadum). Acta

830 Hydrob Sin 31:190-195

831 Martinez M (2003) Condition, prolonged swimming performance and muscle metabolic

832 capacities of cod Gadus morhua. J Exp Biol 206:503-511. doi: 10.1242/jeb.00098

833 McKenzie DJ (2001) Effects of dietary fatty acids on the respiratory and cardiovascular

834 physiology of fish. Comp Biochem Physiol A Mol Integr Physiol 128:605-619. doi:

$835 \quad 10.1016 / \mathrm{S} 1095-6433(00) 00338-\mathrm{X}$

836 McKenzie DJ, Higgs DA, Dosanjh BS, Deacon G, Randall DJ (1998) Dietary fatty acid

837 composition influences swimming performance in Atlantic salmon (Salmo salar) in seawater.

$838 \quad$ Fish Physiol Biochem 19:111-122

839 Milinkovitch T, Lucas J, Le Floch S, Thomas-Guyon H, Lefrançois C (2012) Effect of 840 dispersed crude oil exposure upon the aerobic metabolic scope in juvenile golden grey mullet 841 (Liza aurata). Mar Poll Bull 64(4):865-871 
842 Mommsen TP, Vijayan MM, Moon TW (1999) Cortisol in teleosts: dynamics, mechanisms of 843 action, and metabolic regulation. Rev Fish Biol Fish 9:211-268.

844 Nabauer M, Ellis-Davies GC, Kaplan JH, Morad M (1989) Modulation of $\mathrm{Ca}^{2+}$ channel 845 selectivity and cardiac contraction by photorelease of $\mathrm{Ca}^{2+}$. Am J Physiol 256:H916-920

846 Owens NJP, Cook D, Colebrook M, Hunt H, Reid PC (1989) Long term trends in the 847 occurrence of Phaeocystis sp in the North-East Atlantic. J Mar Biol Assoc UK 69:813-821

848 Paige JA, Liao RL, Hajjar RJ et al et al (1996) Effect of a high omega-3 fatty acid diet on 849 cardiac contractile performance in Oncorhynchus mykiss. Cardiovasc Res 31:249-262

850 Pahl SL, Lewis DM, Chen F, King KD (2010) Heterotrophic growth and nutritional aspects of 851 the diatom Cyclotella cryptica (Bacillariophyceae): Effect of some environmental factors. J 852 Biosci Bioeng 109:235-239. doi: 10.1016/j.jbiosc.2009.08.480

853 Regan MD, Kuchel LJ, Huang SSY, et al. (2010) The effect of dietary fish oil and poultry fat 854 replacement with canola oil on swimming performance and metabolic response to hypoxia in 855 stream type spring Chinook salmon parr. Aquaculture 308:183-189. doi: $856 \quad 10.1016 /$ j.aquaculture.2010.08.014

857 Reidy SP, Kerr SR, Nelson JA (2000) Aerobic and anaerobic swimming performance of 858 individual Atlantic cod. J Exp Biol 203:347-357

859 Roessler PG (1988) Effect of silicon deficiency on lipid composition and metabolism in the 860 diatom Cyclotella cryptic. J Phycol 24:394-400

861 Rousseau E, Smith JS, Meissner G (1987) Ryanodine modifies conductance and gating 862 behaviour of single $\mathrm{Ca}^{2+}$ Release channels. Am J Physiol 253:364-368

863 Sargent JR, Tocher DR, Bell JG (2002) The lipids (Third edition). In: Halver JE, Hardy RW 864 (Eds) Fish Nutrition, Academic Press, London, pp 182-259

865 Schreck CB (1982) Stress and rearing of salmonids. Aquaculture 28:241-249 
Schurmann H, Steffensen JF (1994) Spontaneous swimming activity of Atlantic cod Gadus morhua exposed to graded hypoxia at three temperatures. J Exp Biol 197:129-142

Shiels HA, Blank JM, Farrell AP, Block BA (2004) Electrophysiological properties of the L-

type $\mathrm{Ca}^{2+}$ current in cardiomyocytes from bluefin tuna and Pacific mackerel. Am J Physiol

Reg Int Comp Physiol 286:R659-668

871

872

873

874

875

876

877

878

879

880

881

882

883

884

885

886

Shiels HA, Stevens ED, Farrell AP (1998) Effect of temperature adrenaline and ryanodine on power production in trout (Oncorhynchus mykiss) ventricular trabeculae. J Exp Biol $201: 2701-2710$

Sidell B D, Driezic W.R. (2014) Relationship between cardiac energy metabolism and cardiac work demand in fishes. In: Gilles $\mathrm{R}$ (Eds) Circulation, respiration and metabolism proceedings in life science, Springer, Berlin pp 386-401

Tirri R, Lehto H (1984) Alpha and beta adrenergic control of contraction force of perch heart (Perca fluviatilis) in vitro. Comp Biochem Physiol C 77:301-304

Tirri R, Ripatti P (1982) Inhibitory adrenergic control of heart rate of perch (Perca fluvialitis) in vitro. Comp Biochem Physiol C 73:399-340

Tocher DR (2010) Fatty acid requirements in ontogeny of marine and freshwater fish. Aquac Res 41:717-732. doi: 10.1111/j.1365-2109.2008.02150.x

Trenzado CE, Morales AE, de la Higuera M (2006) Physiological effects of crowding in rainbow trout Oncorhynchus mykiss selected for low and high stress responsiveness. Aquaculture 258: 583-593

Turner N, Else PL, Hulbert AJ (2003) Docosahexaenoic acid (DHA) content of membranes determines molecular activity of the sodium pump: implications for disease states and metabolism. Naturwissenschaften 90:521-523. doi: 10.1007/s00114-003-0470-z

Vornanen M (1997) Sarcolemmal $\mathrm{Ca}^{2+}$ influx through L-type $\mathrm{Ca}^{2+}$ channels in ventricular myocytes of a teleost fish. Am J Physiol Reg Int Comp Physiol 272:R1432-R1440 
891 Vornanen M (1998) L-type $\mathrm{Ca}^{2+}$ current in fish cardiac myocytes: effects of thermal 892 acclimation and beta-adrenergic stimulation. J Exp Biol 201:533-547

893 Vagner M, Lefrançois C, Ferrari RS, et al. (2008) The effect of acute hypoxia on swimming 894 stamina at optimal swimming speed in flathead grey mullet Mugil cephalus. Mar Biol 895 155:183-190. doi: 10.1007/s00227-008-1016-x

896 Wagner G., Balfry S., Higgs D., et al. (2004) Dietary fatty acid composition affects the repeat 897 swimming performance of Atlantic salmon in seawater. Comp Biochem Physiol A Mol Integr 898 Physiol 137:567-576. doi: 10.1016/j.cbpb.2003.11.005

899 Webb PW (1975) Acceleration performance of rainbow trout (Oncorhynchus mykiss). J Exp $900 \quad$ Biol 63:451-465

901 Wendelaar Bonga S E (1997) The stress response in fish. Physiol Rev 77:591-625

902 Yan GJ, He WK, Cao ZD, Fu SJ (2013) An interspecific comparison between morphology 903 and swimming performance in cyprinids. J Evolution Biol 26: 1802-1815

904 Zambonino-Infante JL, Claireaux G, Ernande B, Jolivet A, Quazuguel P, Severe A, Huelvan 905 C, Mazurais M (2013) Hypoxia tolerance of common sole juveniles depends on dietary 906 regime and temperature at the larval stage: evidence for environmental conditioning. P Roy 907 Soc B-Biol Sci 280:1471-2954

908 Zhao WW, Pang X, Peng JL, Cao ZD, Fu SJ (2012) The effects of hypoxia acclimation 909 exercise training and fasting on swimming performance in juvenile qingbo (Spinibar 910 bussinensis). Fish Physiol Biochem 38:1367-1377

911 Zuo R, Ai Q, Mai K, et al. (2012) Effects of dietary n-3 highly unsaturated fatty acids on 912 growth, nonspecific immunity, expression of some immune related genes and disease 913 resistance of large yellow croaker (Larmichthys crocea) following natural infestation of 914 parasites (Cryptocaryon irritans). Fish Shellfish Immunol 32:249-258. doi: $915 \quad$ 10.1016/j.fsi.2011.11.005 


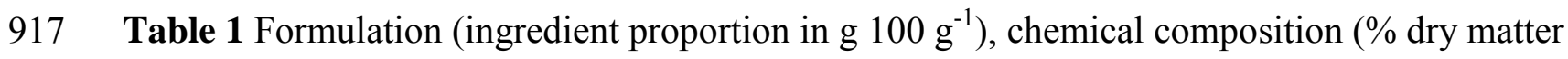
$918 \mathrm{DM} \pm$ standard error SE; $\mathrm{n}=3$ ) and fatty acid composition in total lipids TL (\% fatty acid 919 methyl ester FAME $\pm \mathrm{SE} ; \mathrm{n}=3$ ) of the two experimental diets (standard $\mathrm{n}-3$ HUFA diet SD 920 and low-n-3 HUFA LD diet). Fatty acids for which percentage was lower than $0.2 \%$ FAME 921 are not represented. Each MUFA is represented as a sum of n-7, n-9 and n-11 FA

\begin{tabular}{lcc}
\hline Ingredients $^{a}$ & SD diet & LD diet \\
\hline Fish meal LT 94 & 17 & 17 \\
Casein & 30 & 30 \\
Soy oil & 2 & 10 \\
Fish oil & 8 & 0 \\
Precooked starch & 30 & 30 \\
Vitamin mixture $^{\mathrm{b}}$ & 8 & 8 \\
Mineral mixture $^{\mathrm{c}}$ & 4 & 4 \\
Betaine & 1 & 1
\end{tabular}

Chemical composition

\begin{tabular}{lcc}
\hline Dry matter (\%) & $91.0 \pm 0.1$ & $92.0 \pm 0.1$ \\
Crude protein (\% DM) & $34.7 \pm 0.0$ & $41.3 \pm 0.2$ \\
Crude fat (\% DM) & $11.7 \pm 0.3$ & $10.7 \pm 0.1$ \\
Ash (\% DM) & $7.8 \pm 0.2$ & $6.6 \pm 0.4$ \\
HUFA n-3 (\% DM) & $1.2 \pm 0.0$ & $0.2 \pm 0.0$
\end{tabular}

FA composition in TL

\begin{tabular}{lcc}
\hline $14: 0$ & $3.59 \pm 0.04$ & $0.59 \pm 0.02$ \\
$16: 0$ & $11.84 \pm 0.04$ & $11.32 \pm 0.02$ \\
$18: 0$ & $2.94 \pm 0.01$ & $4.62 \pm 0.01$ \\
$20: 0$ & $0.27 \pm 0.00$ & $0.46 \pm 0.01$ \\
$\Sigma$ SFA & $19 \pm 0.09$ & $17.63 \pm 0.04$ \\
$16: 1$ & $4.03 \pm 0.04$ & $0.80 \pm 0.02$ \\
$18: 1$ & $26.80 \pm 0.05$ & $23.09 \pm 0.02$ \\
$20: 1$ & $4.25 \pm 0.12$ & $1.20 \pm 0.00$ \\
$22: 1$ & $4.69 \pm 0.05$ & $1.17 \pm 0.01$ \\
$24: 1$ & $0.43 \pm 0.01$ & $0.12 \pm 0.00$ \\
$\Sigma$ MUFA & $40.58 \pm 0.14$ & $26.42 \pm 0.03$ \\
$18: 2 \mathrm{n}-6$ & $15.3 \pm 0.03$ & $3.63 \pm 0.09$ \\
$20: 4 \mathrm{n}-6$ & $0.38 \pm 0.00$ & $0.09 \pm 0.00$ \\
$\Sigma \mathrm{n}-6$ & $16.54 \pm 0.02$ & $45.84 \pm 0.01$ \\
$18: 3 \mathrm{n}-3$ & $3.73 \pm 0.01$ & $6.38 \pm 0.01$ \\
$18: 4 \mathrm{n}-3$ & $1.05 \pm 0.00$ & $0.18 \pm 0.00$ \\
$20: 4 \mathrm{n}-3$ & $0.91 \pm 0.00$ & $0.08 \pm 0.00$ \\
$20: 5 \mathrm{n}-3$ & $4.49 \pm 0.01$ & $0.79 \pm 0.01$ \\
$22: 5 \mathrm{n}-3$ & $1.62 \pm 0.01$ & $0.11 \pm 0.00$ \\
$22: 6 \mathrm{n}-3$ & $6.24 \pm 0.06$ & $1.32 \pm 0.01$ \\
$\Sigma \mathrm{n}-3$ & $18.28 \pm 0.07$ & $8.87 \pm 0.03$ \\
\hline
\end{tabular}




\begin{tabular}{lcc}
\hline$\Sigma$ HUFA n-3 & $13.51 \pm 0.08$ & $2.31 \pm 0.02$ \\
$\mathrm{n}-3 / \mathrm{n}-6$ & $1.11 \pm 0.01$ & $0.19 \pm 0.00$ \\
DHA / EPA & $1.39 \pm 0.01$ & $1.68 \pm 0.02$ \\
ARA / EPA & $0.08 \pm 0.00$ & $0.12 \pm 0.00$ \\
\hline \multicolumn{2}{c}{${ }^{\mathrm{a}}$ Sources: fish meal LT $94:$ Norse (Fyllingsdalen, Norway); casein: Sigma-Aldrich }
\end{tabular}

923 (Germany); soy oil: Système U (Créteil, France); fish oil: pure cod oil Cooper (Melun, 924 France); precooked starch: Prégéflo Roquette frères (Lestrem, France); vitamin mixture 925 (INRA Jouy-en-Josas, France)

$926 \quad{ }^{\mathrm{b}}$ Vitamin mixture $\left(\mathrm{g} \mathrm{kg}^{-1}\right.$ vitamin mix): retinyl acetate, 1; cholecalciferol, 2 5; DL- $\alpha$ 927 tocopheryl acetate, 5; menadione, 1; thiamine-HCL, 0 1; riboflavin, 0 4; D-calcium 928 panththenate, 2; pyridoxine-HCL, 0 3; cyanocobalamin, 1; niacin, 1; choline, 200; ascorbic 929 acid (ascorbyl polyphosphate), 5; folic acid, 0 1; D-biotin, 1; meso-inositol, 30

$930 \quad{ }^{\mathrm{c}}$ Mineral mixture ( $\mathrm{g} \mathrm{kg}^{-1}$ mineral mix): KCl, 90; KI, 0 04; $\mathrm{CaHPO}_{4} 2 \mathrm{H}_{2} \mathrm{O}, 500$; $\mathrm{NaCl}$, 931 40; $\mathrm{CuSO}_{4} 5 \mathrm{H}_{2} \mathrm{O}, 3 ; \mathrm{ZnSO}_{4} 7 \mathrm{H}_{2} \mathrm{O}, 4 ; \mathrm{CoSO}_{4}, 0$ 02; $\mathrm{FeSO}_{4} 7 \mathrm{H}_{2} \mathrm{O}, 20 ; \mathrm{MnSO}_{4} \mathrm{H}_{2} \mathrm{O}, 3 ; \mathrm{CaCo}_{3}$, $932 \quad 215 ; \mathrm{MgOH}, 124 ; \mathrm{Na}_{2} \mathrm{SeO}_{3}, 0$ 03; $\mathrm{NaF}, 1$

933 Abbreviations: ARA: arachidonic acid; DHA docosahexaenoic acid; EPA: ecosapentaenoic 934 acid; HUFA: highly unsaturated fatty acids; MUFA: mono-unsaturated fatty acids; SFA: 935 saturated fatty acids

936

937

938

939

940 
942 Table 2 Summary of all physiological and biochemical analyses performed in this study. For

943 each analyse, the number of fish sampled $(\mathrm{N})$ for each experimental condition (standard n-3

944 HUFA dietary group and low-n-3 HUFA LD dietary group), and the sampling period are

945 indicated. + Indicates paired data points, i.e. measurements performed on the same fish

\begin{tabular}{|c|c|c|}
\hline Analyses & $\begin{array}{l}\text { Fish replication for each } \\
\text { experimental condition }\end{array}$ & $\begin{array}{r}\text { Sampling period }^{946} \\
947\end{array}$ \\
\hline $\begin{array}{l}\text { Growth performances (fresh } \\
\text { weight, total and standard } \\
\text { length, height, width, SGR, } \\
\text { Fulton index) }\end{array}$ & $\mathrm{N}=40$ & $\begin{array}{l}\text { Each month during } 68 \\
\text { months } \\
\end{array}$ \\
\hline $\begin{array}{l}\text { Lipid analyses in white } \\
\text { muscle } \dagger\end{array}$ & $\mathrm{N}=12$ & $\begin{array}{l}\text { After the 5-month } \\
\text { experimental period }\end{array}$ \\
\hline $\begin{array}{l}\text { Swimming performance } \\
\left(\mathrm{U}_{\text {crit }}, \mathrm{SMR}, \mathrm{AMR}, \mathrm{AS}\right) \dagger\end{array}$ & $\mathrm{N}=12$ & $\begin{array}{l}951 \\
\text { After the 5-month } \\
\text { experimental period } \\
952\end{array}$ \\
\hline Anaerobic metabolism $\dagger$ & $\mathrm{N}=12$ & $\begin{array}{l}\text { After the 5-month } \\
\text { experimental perigd } 953\end{array}$ \\
\hline Haematocrit $\dagger$ & $\mathrm{N}=12$ & $\begin{array}{l}\text { After the 5-month } \\
\text { experimental perigd4 }\end{array}$ \\
\hline Osmolality $\uparrow$ & $\mathrm{N}=12$ & $\begin{array}{l}\text { After the 5-month } \\
\text { experimental peri8 } 85\end{array}$ \\
\hline Hepato-somatic index $\dagger$ & $\mathrm{N}=12$ & $\begin{array}{l}\text { After the 5-month } \\
\text { experimental period } 6\end{array}$ \\
\hline Cardiac performances & $\mathrm{N}=8$ & $\begin{array}{l}\text { After the } 5 \text {-month } 57 \\
\text { experimental period }\end{array}$ \\
\hline
\end{tabular}

959 rate; $S M R$ : standard metabolic rate; $\mathrm{U}_{\text {crit }}$ : critical swimming speed. 
961 Table 3 Total lipid TL content, neutral lipid NL content, polar lipid PL content ( $\mathrm{mg} \mathrm{g}^{-1}$ of dry

962 weight), fatty acid profile of NL and PL ( $\%$ of fatty acids methyl esters FAME) in Liza aurata

963 white muscle according to rearing conditions (LD: fish fed the low-n-3 HUFA diet; and SD:

964 fish fed the standard n-3 HUFA diet) Values are mean \pm standard error $(\mathrm{n}=28$ for SD group

965 and $\mathrm{n}=16$ for LD group) Statistical significance of diet is indicated through the $P, F$ and $d f$

966 values (one-way ANOVA)

\begin{tabular}{lcccccc}
\hline & \multicolumn{2}{c}{ Fish composition } & \multicolumn{3}{c}{ Statistical analysis } \\
\hline & SD group & LD group & $P$ & $F$ & $d f_{1}$ & $d f_{2}$ \\
\cline { 2 - 7 } TL & $29.34 \pm 2.33$ & $30.65 \pm 3.46$ & 0.747 & 0.1 & 1 & 43 \\
NL & $23.45 \pm 2.41$ & $22.34 \pm 3.03$ & 0.77 & 0.08 & 1 & 43 \\
PL & $5.79 \pm 0.46$ & $7.87 \pm 1.53$ & 0.12 & 2.47 & 1 & 43 \\
\hline
\end{tabular}

NL

\begin{tabular}{|c|c|c|c|c|c|c|}
\hline $14: 0$ & $4.06 \pm 0.10$ & $2.71 \pm 0.12$ & $<0.001$ & 70.8 & 1 & 43 \\
\hline $16: 0$ & $19.08 \pm 0.25$ & $17.44 \pm 0.42$ & $<0.001$ & 12.9 & 1 & 43 \\
\hline $18: 0$ & $2.27 \pm 0.04$ & $2.55 \pm 0.04$ & $<0.001$ & 23.5 & 1 & 43 \\
\hline $20: 0$ & $0.23 \pm 0.01$ & $0.27 \pm 0.01$ & $<0.001$ & 16.7 & 1 & 43 \\
\hline$\Sigma$ SFA & $25.86 \pm 0.30$ & $23.17 \pm 0.49$ & $<0.001$ & 24.5 & 1 & 43 \\
\hline $16: 1$ & $7.92 \pm 0.21$ & $5.52 \pm 0.22$ & $<0.001$ & 56.0 & 1 & 43 \\
\hline $18: 1$ & $26.10 \pm 0.34$ & $23.98 \pm 0.35$ & $<0.001$ & 16.1 & 1 & 43 \\
\hline$\Sigma$ MUFA & $44.22 \pm 0.49$ & $35.85 \pm 0.61$ & $<0.001$ & 109.2 & 1 & 43 \\
\hline $18: 2 n-6$ & $11.85 \pm 0.75$ & $28.05 \pm 1.26$ & $<0.001$ & 139.9 & 1 & 43 \\
\hline $20: 4 n-6$ & $0.37 \pm 0.03$ & $0.26 \pm 0.02$ & $<0.001$ & 7.6 & 1 & 43 \\
\hline$\sum n-6$ & $13.03 \pm 0.75$ & $29.14 \pm 1.26$ & $<0.001$ & 137.8 & 1 & 43 \\
\hline $18: 3 n-3$ & $2.23 \pm 0.06$ & $3.20 \pm 0.09$ & $<0.001$ & 89.3 & 1 & 43 \\
\hline $20: 5 n-3$ & $2.38 \pm 0.09$ & $1.35 \pm 0.15$ & $<0.001$ & 40.4 & 1 & 43 \\
\hline $22: 6 n-3$ & $3.78 \pm 0.11$ & $1.62 \pm 0.24$ & $<0.001$ & 86.8 & 1 & 43 \\
\hline$\sum n-3$ & $11.47 \pm 0.22$ & $7.62 \pm 0.49$ & $<0.001$ & 66.3 & 1 & 43 \\
\hline$\Sigma$ HUFA n-3 & $8.55 \pm 0.22$ & $3.98 \pm 0.50$ & $<0.001$ & 94.7 & 1 & 43 \\
\hline$n-3 / n-6$ & $0.92 \pm 0.03$ & $0.29 \pm 0.05$ & $<0.001$ & 144.4 & 1 & 43 \\
\hline DHA / EPA & $1.62 \pm 0.06$ & $1.22 \pm 0.07$ & $<0.001$ & 19.2 & 1 & 43 \\
\hline ARA / EPA & $0.15 \pm 0.01$ & $0.21 \pm 0.01$ & $<0.001$ & 18.7 & 1 & 43 \\
\hline \multicolumn{7}{|l|}{ PL } \\
\hline $14: 0$ & $5.02 \pm 0.29$ & $4.00 \pm 0.24$ & 0.02 & 5.7 & 1 & 42 \\
\hline $16: 0$ & $19.40 \pm 0.49$ & $17.77 \pm 0.55$ & 0.03 & 4.5 & 1 & 42 \\
\hline 18:0 & $5.46 \pm 0.54$ & $4.73 \pm 0.48$ & 0.37 & 0.8 & 1 & 42 \\
\hline $20: 0$ & $0.18 \pm 0.01$ & $0.17 \pm 0.01$ & 0.40 & 0.7 & 1 & 42 \\
\hline$\Sigma$ SFA & $30.41 \pm 0.55$ & $26.96 \pm 0.52$ & $<0.001$ & 17.3 & 1 & 42 \\
\hline $16: 1$ & $7.64 \pm 0.40$ & $6.18 \pm 0.38$ & 0.02 & 5.8 & 1 & 42 \\
\hline $18: 1$ & $18.01 \pm 0.49$ & $16.47 \pm 0.44$ & 0.04 & 4.4 & 1 & 42 \\
\hline$\Sigma$ MUFA & $31.85 \pm 0.86$ & $26.59 \pm 0.76$ & $<0.001$ & 17.0 & 1 & 42 \\
\hline
\end{tabular}




\begin{tabular}{lcccccc}
\hline $18: 2 \mathrm{n}-6$ & $10.06 \pm 0.72$ & $24.79 \pm 1.19$ & $<0.001$ & 127.3 & 1 & 42 \\
$20: 4 \mathrm{n}-6$ & $1.42 \pm 0.17$ & $1.13 \pm 0.15$ & 0.25 & 1.4 & 1 & 42 \\
$\Sigma \mathrm{n}-6$ & $12.28 \pm 0.69$ & $26.81 \pm 1.16$ & $<0.001$ & 132.6 & 1 & 42 \\
$18: 3 \mathrm{n}-3$ & $2.62 \pm 0.15$ & $4.22 \pm 0.17$ & $<0.001$ & 44.1 & 1 & 42 \\
$20: 5 \mathrm{n}-3$ & $4.85 \pm 0.22$ & $3.24 \pm 0.26$ & $<0.001$ & 20.6 & 1 & 42 \\
$22: 6 \mathrm{n}-3$ & $6.69 \pm 0.76$ & $3.80 \pm 0.66$ & $<0.05$ & 6.5 & 1 & 42 \\
$\Sigma \mathrm{n}-3$ & $18.74 \pm 0.98$ & $13.94 \pm 0.92$ & $<0.01$ & 10.5 & 1 & 42 \\
$\Sigma$ HUFA n-3 & $15.06 \pm 1.11$ & $8.88 \pm 1.04$ & $<0.001$ & 13.8 & 1 & 42 \\
$\mathrm{n}-3 / \mathrm{n}-6$ & $1.60 \pm 0.10$ & $0.56 \pm 0.07$ & $<0.001$ & 51.4 & 1 & 42 \\
DHA / EPA & $1.34 \pm 0.11$ & $1.16 \pm 0.14$ & 0.35 & 0.9 & 1 & 42 \\
ARA / EPA & $0.28 \pm 0.02$ & $0.35 \pm 0.03$ & 0.07 & 3.5 & 1 & 42 \\
\hline \multicolumn{5}{c}{ Abbreviations: ARA: arachidonic acid; $d f_{1}:$ degree of freedom of numerator; $d f_{2}:$}
\end{tabular}

967 Abbreviations: ARA: arachidonic acid; $d f_{1}$ : degree of freedom of numerator; $d f_{2}$ :

968 degree of freedom of denominator; DHA docosahexaenoic acid; EPA: ecosapentaenoic acid;

969 HUFA: highly unsaturated fatty acids; MUFA: mono-unsaturated fatty acids; SFA: saturated

970 fatty acids 
Table 4 Critical swimming speed ( $\mathrm{U}_{\text {crit }}$ ), standard metabolic rate (SMR), active metabolic rate (AMR), aerobic scope (AS), haematocrit, plasma osmolality, Fulton index, and hepatosomatic index (HSI) in SD (standard n-3 HUFA fed fish) and LD (low-n-3 HUFA fed fish) groups (mean \pm standard error). $\mathrm{N}$ (number of replicates) is indicated below each value. The statistical difference between both groups is indicated $\left(F, P, d f_{1}\right.$ :

975

\begin{tabular}{|c|c|c|c|c|c|c|c|c|c|}
\hline & $\begin{array}{c}\text { SGR } \\
\left(\% \text { day }^{-1}\right)\end{array}$ & $\begin{array}{c}\mathrm{U}_{\text {crit }} \\
\left.(\mathrm{BL} \mathrm{s})^{-1}\right)\end{array}$ & $\begin{array}{c}\mathrm{SMR} \\
\left(\mathrm{mgO}_{2} \mathrm{~kg}^{-1} \mathrm{~h}^{-1}\right)\end{array}$ & $\begin{array}{c}\text { AMR } \\
\left(\mathrm{mgO}_{2} \mathrm{~kg}^{-1} \mathrm{~h}^{-1}\right)\end{array}$ & $\begin{array}{c}\mathrm{AS} \\
\left(\mathrm{mgO}_{2} \mathrm{~kg}^{-1} \mathrm{~h}^{-1}\right)\end{array}$ & $\begin{array}{c}\text { Haematocrit } \\
(\%)\end{array}$ & $\begin{array}{l}\text { Osmolality } \\
\left(\text { mosmol L }^{-1}\right)\end{array}$ & $\begin{array}{l}\text { Fulton } \\
\text { index }\end{array}$ & HSI \\
\hline $\begin{array}{l}\text { SD } \\
\text { group }\end{array}$ & $\begin{array}{c}0.4 \pm 0.02 \\
(\mathrm{n}=40)\end{array}$ & $\begin{array}{c}6.4 \pm 0.2 \\
(n=11)\end{array}$ & $\begin{array}{c}66.5 \pm 11.8 \\
(\mathrm{n}=10)\end{array}$ & $\begin{array}{c}590.2 \pm 72.0 \\
(\mathrm{n}=10)\end{array}$ & $\begin{array}{c}523.7 \pm 67.1 \\
(\mathrm{n}=10)\end{array}$ & $\begin{array}{c}35.3 \pm 2.4 \\
(\mathrm{n}=12)\end{array}$ & $\begin{array}{c}374.1 \pm 6.3 \\
(\mathrm{n}=11)\end{array}$ & $\begin{array}{c}0.96 \pm 0.02 \\
(\mathrm{n}=12)\end{array}$ & $\begin{array}{c}0.22 \pm 0.05 \\
(\mathrm{n}=12)\end{array}$ \\
\hline $\begin{array}{l}\text { LD } \\
\text { group }\end{array}$ & $\begin{array}{c}0.3 \pm 0.01 \\
(\mathrm{n}=40)\end{array}$ & $\begin{array}{c}6.9 \pm 0.4 \\
(\mathrm{n}=10)\end{array}$ & $\begin{array}{c}38.5 \pm 8.7 \\
(\mathrm{n}=10)\end{array}$ & $\begin{array}{c}266.0 \pm 24.8 \\
(n=10)\end{array}$ & $\begin{array}{c}227.5 \pm 23.3 \\
(\mathrm{n}=10)\end{array}$ & $\begin{array}{c}44.1 \pm 2.9 \\
(\mathrm{n}=12)\end{array}$ & $\begin{array}{c}400.2 \pm 10.5 \\
(n=10)\end{array}$ & $\begin{array}{c}0.99 \pm 0.02 \\
(\mathrm{n}=12)\end{array}$ & $\begin{array}{c}0.56 \pm 0.32 \\
(\mathrm{n}=12)\end{array}$ \\
\hline \multicolumn{10}{|c|}{ Statistical analysis } \\
\hline$P$ & 0.009 & 0.276 & 0.071 & 0.001 & 0.001 & 0.041 & 0.048 & 0.305 & 0.304 \\
\hline$F$ & 7.26 & 1.26 & 3.67 & 18.12 & 17.36 & 4.72 & 4.43 & 1.10 & 1.10 \\
\hline$d f 1$ & 1 & 1 & 1 & 1 & 1 & 1 & 1 & 1 & 1 \\
\hline$d f_{2}$ & 72 & 19 & 18 & 18 & 18 & 22 & 19 & 22 & 22 \\
\hline
\end{tabular}




\section{Figure Legends}

978 Fig 1 Oxygen consumption $\left(\mathrm{MO}_{2} ; \mathrm{mg} \mathrm{O}_{2} \mathrm{Kg}^{-1} \mathrm{~h}^{-1}\right.$; mean \pm standard error SE) as a function of 979 swimming speed $\left(\mathrm{BL} \mathrm{s}^{-1}\right)$ for each fish dietary group: Standard-n-3 HUFA fed fish (SD) are 980 represented by squares, and Low-n-3 HUFA fed fish (LD) are represented by triangles (n = 10 981 per experimental condition). Solid line and dotted line indicate exponential curves fitted on $982 \mathrm{MO}_{2}$ as a function of swimming speed before a plateau was attained for the SD and LD 983 groups, respectively (SD group curve: $\mathrm{y}=74.003 \mathrm{e}^{0.3061 \mathrm{x}} ; \mathrm{r}^{2}=0.98$; LD group curve: $\mathrm{y}=$ $\left.984 \quad 45.051 \mathrm{e}^{0.2609 x} ; \mathrm{r}^{2}=0.98\right)$.

985

986 Fig 2 Recovery status of $L$ aurata after the $U_{\text {crit }}$ test for each fish dietary group: 987 Mean excess of post-exercise oxygen consumption ( \pm standard error SE, EPOC in $\mathrm{mgO}_{2} \mathrm{~kg}^{-1}$ ) 988 for each dietary group assessed over the whole recovery period (70 min). A significant 989 difference was observed between the groups $\left(P=0.0037 ; F_{1,18}=4.98\right)$

990

991 Fig 3 Kinetics of calcium fluxes as a function of chemical stimulation for each fish dietary 992 group (standard-n-3 HUFA SD or low-n-3 HUFA LD diet): (a) time to rise (s), (b) time to 993 decay at 50\% (s), and (c) amplitude (V) of calcium concentration measured in fish ventricular 994 myocytes following stimulation by hyperpotassic solution $(100 \mathrm{k}$ at $100 \mathrm{mM})$, ryanodine 995 (RYA at $1 \mu \mathrm{M})$, or adrenaline (AD at $1 \mathrm{mM})$. Results are mean \pm standard error SE with the 996 number of cells tested indicated on each mean. One-way ANOVA revealed no significant 997 effect of $\operatorname{diet}(P>0.05)$; ** indicates that RYA had a significant effect on time to rise at $P<$ $9980.01\left(F_{2,41}=10.29\right)$. 
$1001 \quad$ Fig 1

1002

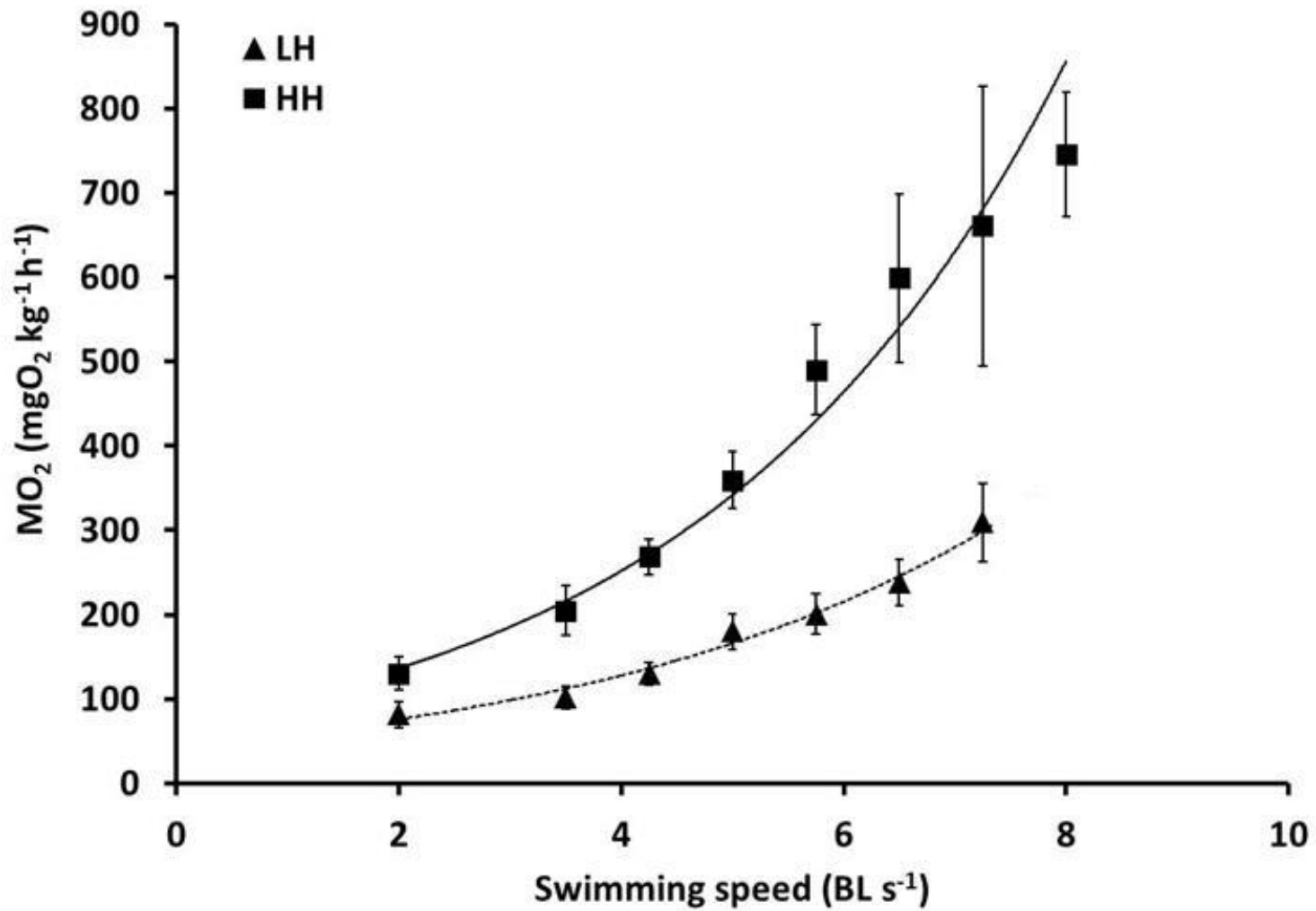

1003

1004

1005 
Fig 2

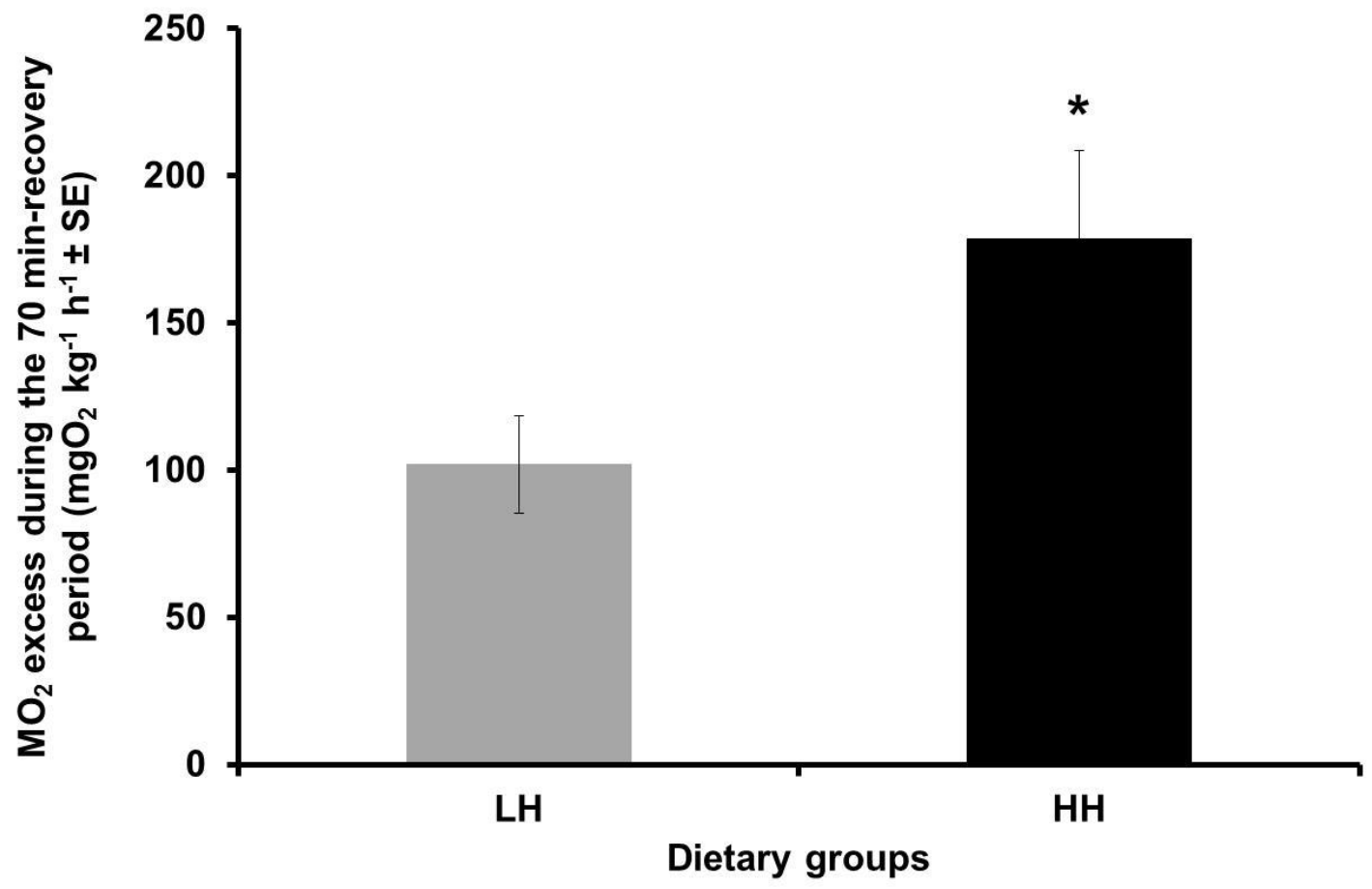

1007

1008

1009

1010

1011

1012

1013

1014

1015

1016

1017

1018

1019

1020

1021 
$1022 \quad$ Fig 3

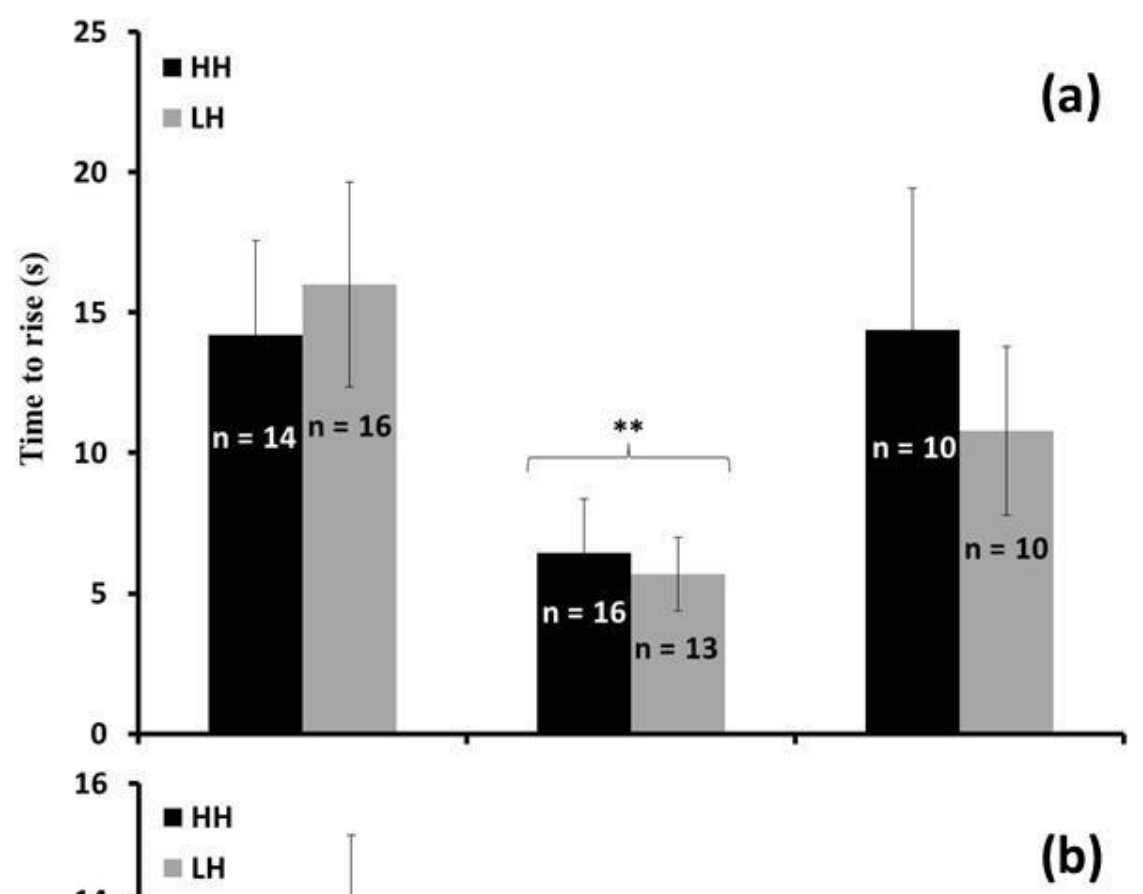

1023

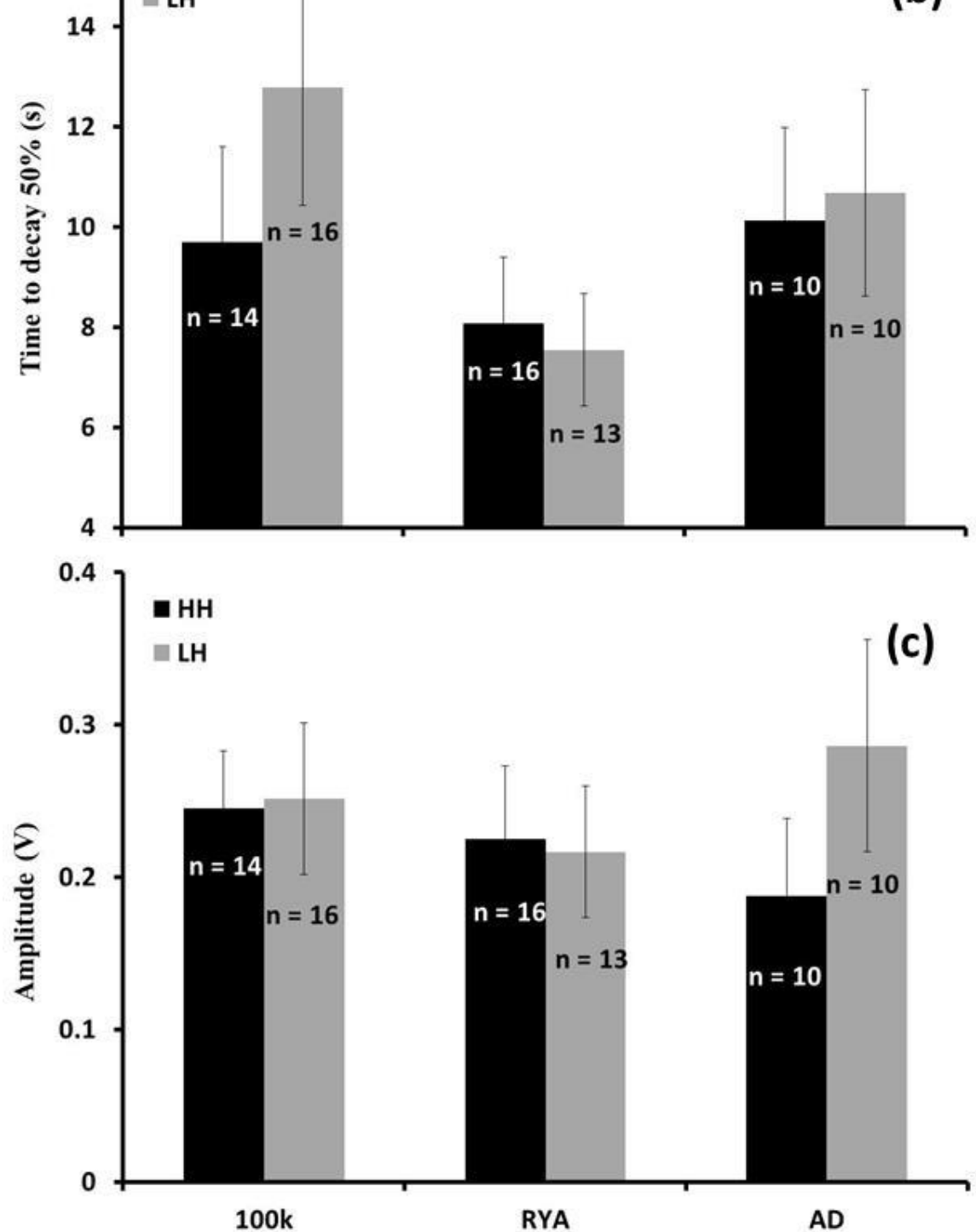

